\title{
LIMNOLOGICAL ASPECTS
} OF ACID PRECIPITATION

Proceedings of the International Workshop held at the Sagamore Lake Conference Center September 25-28, 1978

GEORGE R. HENDREY, Editor

Cosponsored by CORVALLIS ENVIRONMENTAL RESEARCH LABORATORY, UNITED STATES ENVIRONMENTAL PROTECTION AGENCY and BROOKHAVEN NATIONAL LABORATORY LAND AND FRESHWATER ENVIRONMENTAL SCIENCES GROUP DEPARTMENT OF ENERGY AND ENVIRONMENT

BROOKHAVEN NATIONAL LABORATORY ASSOCIATED UNIVERSITIES, INC. 


\section{DISCLAIMER}

This report was prepared as an account of work sponsored by an agency of the United States Government. Neither the United States Government nor any agency Thereof, nor any of their employees, makes any warranty, express or implied, or assumes any legal liability or responsibility for the accuracy, completeness, or usefulness of any information, apparatus, product, or process disclosed, or represents that its use would not infringe privately owned rights. Reference herein to any specific commercial product, process, or service by trade name, trademark, manufacturer, or otherwise does not necessarily constitute or imply its endorsement, recommendation, or favoring by the United States Government or any agency thereof. The views and opinions of authors expressed herein do not necessarily state or reflect those of the United States Government or any agency thereof. 


\section{DISCLAIMER}

Portions of this document may be illegible in electronic image products. Images are produced from the best available original document. 
(Environmental Control Technology and Earth Sciences - TID-4500)

\section{LIMNOLOGICAL ASPECTS OF ACID PRECIPITATION}

Proceedings of the International Workshop

held at the

Sagamore Lake Conference Center

September 25-28, 1978

GEORGE R. HENDREY, Editor

This book was prepared as an account of work sponsored by an wency of the United States Government. Neither the Unitod Statas Government nnr any agency thereof, nor any of their employees, makes any warranty, express or implied, or assumes any legal liability of responsiblitity for the accuracy. completeness, or usefutness of any information. apparatus. product, or process disclosed, or represents that its uso would not intringe privately owned rights, Raterence hesein to any specic not necessarily constitute or imply its endorsement, recommendation, or favoring by the United Stales Government or any agency thereof. The views and opinions of suthors expressed hercin do not

Cosponsored by

CORVALLIS ENVIRONMENTAL RESEARCH LABORATORY, UNITED STATES ENVIRONMENTAL PROTECTION AGENCY

and

BROOKHAVEN NATIONAL LABORATORY.

LAND AND FRESHWATER ENVIRONMENTAL SCIENCES GROUP

DEPARTMENT OF ENERGY AND ENVIRONMENT

BROOKHAVEN NATIONAL LABORATORY

UPTON, NEW YORK 11973 


\section{DISCLAIMER}

This book was prepared as an account of work sponsored by an agency of the. IInited Statcs Govermmenl. Neither the United States Government nor any agency therenf, nor any of their employees, makes any warranty, express or implied, or assumes any legal llability or responsibility for the accuracy, completeness, or usefulness of any information, apparatus, product, or process disclosed, or represents that its use would not infringe privately owned rights. Reference herein to any specific commerrial product, process, or service by trade name, trademark, manufacturer, or otherwise, does not neoesearily constitute in in.ply its endorement, recommendation, or favoring by the United States Government or any agency thereof. The views and opinions of authors expressed herein do not necessarily state or reflect those of the United States Government or any agency thereof.

Printed in the United States of America Available from

National Technical Information Service

U.S. Department of Commerce

5285 Port Royal Road Springfield, VA 22161

Price: Printed Copy $\$ 5.25$; Microfiche $\$ 3.00$ 
This workshop was supported by the United States Environmental Protection Agency, Corvallis Environmental Research Laboratory, under contract number EPA 78-D-F0347 and the United States Department of Energy, Brookhaven National Laboratory, under Contract Number EY-76-C-02-0016.

Special thanks go to Robert Edwards, Tim Slauson, Emmett Soffey (all of the Adirondack Lakes Project staff), and Joan Baker (Cornell University) for taking notes of the presentations and discussions, and to Mitzi McKenna and Barbara Nichols (of BNL) for clerical assistance. 


\section{ABSTRACT}

Lakes and streams in parts of Norway, Sweden, Canada, and the United States are being severely impacted by acidic precipitation. Scientists meeting at Sagamore, New York, agreed that this is the most serious limnological problem today. The factor responsible for determining the sensitivity of surface waters to acidification is alkalinity derived by weathering of soils and bedrock in the watershed. Acidification, defined as a reduction in alkalinity, can be quantified if preacidification alkalinity data exist, but often they do not. Data on $\mathrm{pH}$ and $\mathrm{Ca}$ from surface waters in areas not affected by acid precipitation were compared to similar data from areas which receive precipitation with a weighted average hydrogen ion concentration of $\mathrm{pH}$ <4.6. A semiquantitative estimation of surface water acidification can be made for lakes and streams, where earlier chemietry data are lacking, bàsed on this analysis of $\mathrm{pH}$ and $\mathrm{Ca}$ data.

Biolugical responses to acidification range from a reduction in numbers of species of algae and zooplankton to complete ellmination of all fish life. Major biological processes such as primary production and decomposition may be altcred leading to an accumulation of plant material and organic debris within lakes and streams.

Increased concentrations of aluminum from the $\mu \mathrm{g} / \mathrm{l}$ to $\mathrm{mg} / \mathrm{l}$ range have been found at levels shown to be toxic to fish. These elevated levels apparently result from the exchange of $\mathrm{H}^{+}$and $\mathrm{Al}$ in the watershed. There also appears to be a relationship between lake acidification and the accumulation of mercury in fish.

Problems of aluminum analysis received detailed attention, and watershed mass balances, comparative watershed studies, whole lake manipulations, synoptic surveys, and the liming of acidified waters were discussed. A priority-rated list of recommendations for research was presented. 
Acknowledgments . . . . . . . . . • . • . • • •

Abstract . . . . . . . . . . . . . . . . .

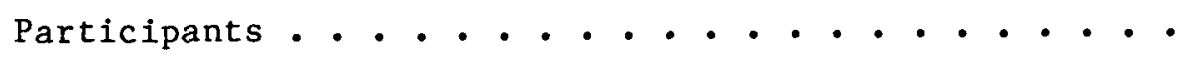

vii

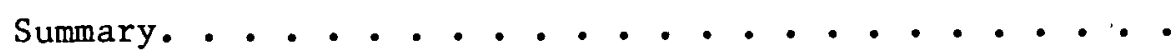

ix

Session I

J. N. Galloway

University of Virginia

pH and Acidity Measurements. • . . . . . . • • •

Session II

M. Johannessen

Norwegian Institute for Water Research

Regional Lake Surveys. . . . . . . . . . . .

Session III

C. Driscoll

Corne11 University

Aluminum Chemistry in Dilute Waters. . . . . . .

Sesstion IV

D. Schindler

Freshwater Institute, Winnepeg

Chemical Budgets and Watershed Acidification . . . .

Session V-A

H. Hultberg

Swedish Water and Air Pollution

Research Laboratory, Gothenberg

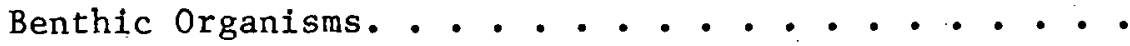


Session V-B

G. Raddum

University of Bergin

Invertebrates: Quality and

Quantity as Fish Food . . . . . . . . . . •

Session VI

G. Hendrey

Brookhaven National Laboratory

Blological Procés̄sès. . • • • . • . . . . .

Session VII

C. Schofield

Cornell University

Toxicity of Metals. . . . . . . . . . . .

Session VIII

W. Dicksen

Swedish Environmental Protection Board, Solna

Liming. . . . . . . . . . . . . . . .

Seocion IXX

G. Likens

Cornell University

Summing-up and Recommendations. . . . . . . . . 


\section{PARTICIPANTS}

\section{Organizing Committee}

G. Hendrey (Chairman)

J. Galloway

D. Schindler

C. Schofield

\section{Contributors}

Dr. Ronald Davis

Deering Hall

University of Maine

Orono, Maine 04473

Dr. William Dickson

Statens Naturvardsverk

Fack

171 Solna

Sweden

Dr. Peter Dillon

Ontario Ministry of the Environment

Rexdale, Ontario

Mr. Charles Driscoll

Department of Environmental

Engineering

Cornell University

Ithaca, New York 14850

Dr. James Galloway

Department of Environmental

Sciences

University of Virginia

Charlottesville, Virg1nia 22903

Dr. Gary E. Glass

Environmental Research Lab

U.S. EPA

6201 Congdon B1vd.

Deluth, Minnesota 55804

Dr. Walt Glooschenko

Geology Section

Process Research Division

National Water Research Institute

Box 5050

Burlington, Ontario

Canada L7R 4AC
Dr. George Hendrey

Environmental Sclences Group

Brookhaven National Laboratory

Upton, New York 11973

Dr. Hans Hultberg

Swedish Water \& Air Pollution

Research Laboratory

Box 5207

S-402 24 Gothenburg 5,

Sweden

Dr. Tom C. Hutchinson

Dept. of Botany

University of Toronto

Toronto, Ontario, Canada

Dr. Merete Johnannessen

Chemistry Section

Norwegian Institute for Water

Research

Box. 333 Blindern

Os 1o 3, Norway

Dr. James Kramer

Dept. of Geology

McMaster University

Hamilton, Ontario

L8S-481 Canada

Dr. Gene Likens

Ecology and Systematics

Cornell University

Ithaca, New York 14850

Dr. Charles Powers

Corvallis Environmental Research

Lab

200 SW 35th Street

Corvallis, Oregon 97330 
Dr. Gunnar Raddum University of Bergin 5000 Bergin, Norway

Dr. David Schindler Freshwater Institute 501 University Crescent Winnipeg, Manitoba R3T 2N6, Canada

Dr. Car1 L. Schofield Department of Natural Resources Connell Univelsity Tthaca, New York. 14853
Dr. David Troutman United States Geological Survey Box 1350

Albany, New York 12201

Dr. Paul Wong

Canada Center for Inland Waters

P. O Box 5050

Burlington, Ontario

Canada LTR 4A6

Dr. Norman Yan

Ontario Ministry of the Envitronment.

Rexdale, Ontario 


\section{SUMMARY}

The International Workshop on Limnological Aspects of Acid Precipitation was organized to bring together a number of scientists who have been studying the effects of acid precipitation on lakes. The goals were to (1) take stock of the several relevant limnological projects now in progress and to identify research topics currently under Investigation; (2) to identify additional topics which need to be addressed and to establish priorities among these topics; and (3) to discuss chemical and biological methods and methodological problems in an informal atmosphere with other persons who are actively engaged in lake research relevant to this specific problem area.

No formal presentations were made at the workshop and a formal workshop report was not anticipated. However, notes were taken during the opening statements of session leaders and during subsequent discussions. These nctes were typed and distributed to the session leaders for amendment during the course of the workshop (with minimal subsequent editing). Portions of a report draft were circulated to some of the participants to help clarify the notes, and additional written materials were added at that time. The notes, with these materials added by participants constitute the workshop report.

The workshop discussion, and supporting presentations of data, demonstrated that acid precipitation is having a dramatic impact on lakes in western Sweden, southern Norway, southeastern Canada, and the northeastern United States. These enormous geographical areas encompass thousands of lakes, many of which are being acidified. The factor primarily responsible for determining the sensitivy of a lake to acidification is its alkalinity, and this is controlled by bedrock and surficial geology of the lake's catchment area. Some areas which are not now seriously acidified are threatenend by current levels of acid precipitation and are likely to be seriously Impacted if acid inputs continue to increase. One such area is the great Canadian Shield, where $50 \%$ or more of the world's freshwaters are located and where alkalinites are extremely low.

The workshop participants agreed that alterations caused by the acidification of lake waters are alarming. Among the many chemical changes are concentrations of aluminum increased to the $\mathrm{ppm}$ range (sufficient to directly cause fish mortalities). Other chemical-biological interactions include increased concentrations of mercury in organisms including algae and fish. The biological responses to acidification range from alterations in phytoplankton community composition to the complete elimination of all fish life. Major alterations in fundamental ecological processes such as primary production and decomposition have been observed in freshwaters due to acidification. A number of investigations into physiological responses of invertebrates indicate that the major response to acid stress is inhibition of osmoregulation and salt loss from the animals. Other cations, particularly $\mathrm{Ca}^{++}$, can mitigate this osmoregulatory imbalance, at least in fish.

Although substantial evidence has been accumulated as to what is happening in acidified lakes, limnologists are just beginning to understand something of why changes occur as they do. Obviously, blological and chemical relationships are complex and one cannot predict the course of events in a lake simply by knowing acid loading and the alkalinity of the waters. Eventually it would be desirable to make predictions as to the types and rates of ecological changes due to lake acidification (given other predictions of chemical inputs). To achieve that predictive ability, answers are needed for 
specific questions concerning the effects of acidification on lake chemistry and bicta. Intensive studies are currently being conducted in Sweden, Norway (the SNSF-Project), Canada (in the Sudbury region and Experimental Lakes Area or ELA), and the United States (the Adirondack Lakes Project, or ALP), which will contribute to an understanding of ecological relationships in acidified lakes.

Several analytical problems were discussed including the interpretation of Gran's plots and determination of Al speciation. These are important to evaluating the components of acidity and the buffering effects of weak acids. On another level, the analyses of lake system responses, four methods are described by the participants:

a. Input/output, mass balance calculations (e.g., ELA and ALP lakes);

b. Comparative watershed studies (e.g., in Norwegian and ALP lakes);

c. Whole lake manipulations (e.g., ELA acidification, and Swedish liwing expertments);

d. Synoptir surveys (e.g., Norwegian and Sudbury region lakes).

The copic of liming (any procedure whereby the $\mathrm{pH}$ of an acidified lake is raised) was discussed. In Sweden, the application of lime to agricultural land at the rate of 5 tons of limestone per hectare every 3 years over $10 \%$ of a watershed will provide ca .05 meq of alkalinity per liter. For acidified Swedish lakes, as much as 50 to $70 \mathrm{~kg} \mathrm{CaCO} /$ ha are needed when liming lakes directly. Both chemical and biological responses to liming were also discussed.

In the final Summary Session, Gene Likens reviewed the major theme expressed during the workshop and synthesized a list of studies, according to priority, which seem essential to advancing our knowledge of lake acidification. This list was accepted by the workshop.

Finally, a couple of hours were spent discussing public perceptions of the acid precipitation problem. This discussion is summarized as follows:

1. Since acid precipitation is a serious environmental problem arising from the use of fossil fuels, the environmental impacts caused by acid precipitation constitute a cost which should be included in the decisionmaking process concerning energy policy. For example, the natural buffering capacity of a catchment area may be entirely consumed by increased acid in precipitation. What is, the cost of replacing all of this buffer capacity (e.g., by liming)?

2. The public is poorly informed concerning acid precipitation and, as a consequence, these environmental costs are likely to be ignored in these decision-making processes. 
Session I

- PH AND ACIDITY MEASUREMENTS

J. Galloway

Problems requiring future research were recognized in these areas: BASIC TECHNOLOGY

Sampling

How can samples be taken to prevent changes in temperature and composition? Specifically, sampling systems for measuring acid neutralizing fluxes from sediments and biological systems and measurements in anaerobic systems need advancement.

Analysis

To determine sources of acidity and the extent of buffering systems in acid lakes, measurements of the contribution of $\mathrm{Al}, \mathrm{Fe}$, strong acids, and organic acids to lake acidity need to be standardized. Development in three areas is suggested: (1) improvements in the analytical chemistry and data analysis of acidity measurements, specifically, interpretation of Gran's plots, analysis of aluminum speciation, and determination of organic acid pK's; (2) the development of a modeling approach using sensitivity analysis to determine the importance of potential acid species; and (3) acid precipitation acidifies oligotrophic lakes. Besides a drop in the $\mathrm{pH}$ of acidified lakes, there is also a shift in buffering systems from a carbonic acid system to an aluminum and organic acid buffering system.

Because the effects of lake acidification on aquatic ecosystems are dependent on both $\mathrm{pH}$ and degree and type of buffering systems, it is necessary to further investigate the weak acid buffering systems.

Errors in estimating the strong acid content or alkalinity of samples may be introduced by utilizing Gran's plots derived from titrations over f1xed $\mathrm{pH}$ ranges if weak acids with $\mathrm{pK}$ 's in the range of 3 to 5 and $\mathrm{C}_{\mathrm{A}} 10$ to 100 $\mu$ mol/liter are present. For example, assume a water with alkalinity $=0$ and $\mathrm{C}_{\mathrm{A}}=100 \mu$ mol/liter of a $\mathrm{pK}_{\mathrm{a}} 4$ weak arid. The initial $\mathrm{pH}$ is 4.209 and the estimated alkalinity (or strong acid) will be $-48 \mu \mathrm{eq} / /$ liter $(48 \mu \mathrm{eq} . / 1$ iter strong acid) if titration data below $\mathrm{pH} 3.8$ are used for extrapolation to the equivalence point. The Gran's plot is linear, but the slope is only $\sim 94 \%$ of the theoretical strong acid slope, thus causing the error in estimated alkalinfty (strong acid). The interpretation that strong acid is present in the sample is erroneous in this case.

\section{SYSTEMS APPROACH}

Concurrent with improving the basic sampling and analytical techniques is the development of whole watershed studies. This requires a systems approach and can be broken down into two stages. (1) Input/output budgets treat the lake system as a black box. Measurements of inputs of the acids into the box (from atmosphere, watershed, and sediments) are compared to 
measurements of output to see how the lake alters the acidity structure. This provides information on proton sources and sinks for the lake. (2) Acidification/neutralization processes, concurrent with (1), the need to open the black box and do research on the processes occurring within the lake that account for the changes in acidity.

Two Methods for Studying Watershed Systems

1. Comparative lake investigation. Select lake systems with different acidity structures and use differences in the natural systems to elucidate importance of various processes.

2. Lake manipulation. Lakes can be artifically acidified or neutra1ized. This enables a rapid determination of lake response to different acidity regimes.

SUMMARY FOLLOWING DIECUEEION

(Prepared by J. Kramer)

The diccucsion focusca upon the analysis of low alkalfaity walers where other fractions (especially at $\mathrm{pH} 4$ to 5 ) than carbonate may contribute to the analysis.

The method is based upon computer reduction (Gran analysis) of a prepared (filtered, unfiltered, etc.) sample $(100 \mathrm{~g}$ ) in $0.01 \mathrm{~N} \mathrm{NaC1}$ or $\mathrm{KCl}$. Typically, $1 \mathrm{~g}$ of $10 \mathrm{M}$ salt is added to the sample. The analytical setup involved a digitally recording $\mathrm{pH}$ meter and an auto-analyzer pump delivering 0.01 to $0.001 \mathrm{~N} \mathrm{HC1}$. $\mathrm{pH}$ is monitored every minute against time (volume acid added). The sample is weighed before and after acid addition, and the titration is carried out to a pH of about 3.5. The sample is stirred continuously during analysis, and a combination gel reference $\mathrm{pH}$ electrode is used. Multiple sample analysis is carried out using an automatic switch. Typically 50 to 200 data points (50 to 200 minutes) per analysis are obtained.

Initial reduction of data is obtained assuming a two proton acid system. This system* is then reanalyzed in areas where the curve is not linear or the derived stability constant deviates for the carbonate system. Reproducibility and standard error of estimate for total alkalinity is typically less than $0.01 \%$. The total analysis has been carried out on natural samples with alkalinites as low as $60 \mu \mathrm{eq} / 1$. So far all data on natural systems fit a carbonate model within experimental error.

It is proposed that an alkalinity titration be followed immediately by an acidity titration along with computer reduction of data.

Acid standardization and electrode standaridization is carried out using deionized water $0.01 \mathrm{~N} \mathrm{NaCl}$ or $\mathrm{KCl}$ with Gran analysis.

Total alkalinity and carbonate alkalinity (following the Oceanographer's) terminology should he used,

* Alternately and better is to use a step by step reduction of the alkalinity (or acidity curve) with an assumed system following the mass balance/electroneutrality-equilibrium $10 \mathrm{~g}$ of: Seymour, M.D., J.W. Clayton, and Q. Fernando, 1977, (Determination of $\mathrm{pKa}$ values of acid components in atmospheric condensates by linearization of segmented titration curves). Anal. Chem. 49 , 1429-1432; for your own system. 


\section{Session II}

\section{REGIONAL LAKE SURVEYS}

\section{Johannessen}

Multiple watershed and synoptic studies were briefly outlined. Evaluation of acidification based on Norwegian systems was discussed.

\section{SEASONAL VARIATIONS IN LAKE CHEMISTRY}

Multiple watershed studies were instituted in Norway to elucidate yearly, seasonal, and special event variations in water chemistry. To illustrate the effect of the two yearly periods of rapid chemical changes in high waterflow, the autumn rain period and the spring melt season, mean ionic balances for the chemically stable 20-day periods before and after these two events were shown. The winter period when the lake is frozen is a chemically stable period. Spring melts have increased $\mathrm{H}^{+}$concentrations, stable $\mathrm{SO}_{4}$ concentrations, and reductions of all the other ions, which resulted in extremely low ionic strength.

During the summer, the ion content increased. The low $\mathrm{H}^{+}$concentration and the difference between cations and anions suggests that some bicarbonate is present in the period before the autumn rain. In the fall, $\mathrm{H}^{+}$concentrations increased again, carbonate dropped to zero, but the total ion content remained the same. This illustrates the important effect of the spring melt which gives high $\mathrm{H}^{+}$and $\mathrm{SO}_{4}$ concentrations together with extremely low concentrations of all other tons.

In northern Norway, precipitation is acid ( $\mathrm{pH} 4.6$ ), but the amount of precipitation received here is about half that received in southern Norway. Ion concentrations are relatively stable seasonally, but in spring high flow conditions cause a decrease in carbonate, which is apparently replaced by sulfate as the major anion. Conductivity also drops during high flows because of dilution with meltwater. Perhaps the northern conditions represent the transitional period where regional acidification of the waters is beginning to. occur.

\section{LAKC AND RIVER SAMPLING PROGRAMS}

Synoptic sampling of snow and lake water was instituted in 1974 in Norway. Random 50-km squares were chosen from a grid overlaying a map of the country. Specific lakes were chosen for small slze, headwater conditions, and freedom from physical human disturbance. Data from the synoptic sampling allowed isobars for chemical concentrations, e.g., pH in snow, to be drawn across the country for the stable winter conditions. Two major acid stress zones are indicated, one in the north, one in the south. It is important to continue such regional surveys for a number of years and to concentrate on one class of lakes, ideally small headwater ones.

River systems have shown increases in $\mathrm{pH}$ as one goes downstream, but the specific values vary from river to river. A small excess of cations over anions is frequently observed. Organic complexing, underestimation of anions, and different $\mathrm{Al}$ speciation are thought to be possible contributors to the cation excess. 
Plots were made of $\mathrm{pH}$ versus $\mathrm{Ca}$ concentrations observed in a large number of lakes in regions of Norway, where the impacts of acid precipitation are light or nonexistent. A curve was drawn (Figure 1) so that nearly all of these plotted points fell below the line, showing the lowest $\mathrm{pH}$ an unpolluted lake can be expected to have for a particular $\mathrm{Ca}$ concentration. Data from waters in areas which are heavily impacted by acid precipitation (not shown) nearly all fell above the line when plotted on the same figure, indicating that the $\mathrm{H}^{+}$concentration was higher than should be expected on the basis of the $\mathrm{Ca}$ concentration. Using this information to determine whether or not acidification has occurred is a conservative method, since the dividing line was drawn so as to be above the data points observed in nonacidified areas. This plot is a practical tool for evaluating whether or not acidification has uccurred, even before one sees very low $\mathrm{pH}$ or fish-kills.

Ca concentration may be a good indicating parameter of acidification as $1 t$ appears to be linearly related to alkalinity for nnnaridified lakes. Thuo a first estimate of acidification would equal the difference between the expected alkalinity of a lake, as predicted by observed Ca ronsentratinn, and the Ca alkalinity correlation for unpolluted lakes, and the current alkalinity, as measured using Gran's plots for strong acids. This measure shows good correlation with precipitation $\mathrm{pH}$, and precipitation $\mathrm{SO}_{4}$ in polluted areas of southern Norway.

Since the most acid lakes also have the highest carbon content, presumably including weak organic acids, the expected alkalinity may be overestimated. To correct the estimate, the weak acid component should be subtracted by using an. organic C term, which is correlated to the weak acids, thus correcting for the maximum reduction of the expected alkalinity that could be caused by, organic carbon:

Acidification $=$ expected Alk $-(2.2+6.7$ (org. $C \mathrm{mg} / 1)+$ Current Alk).

This parameter shows the same regional picture as the uncorrected acidification with lower numbers.

\section{DISCUSSION}

In plotting $\mathrm{pH}$ vs $\mathrm{Ca}$, a stable $\mathrm{Ca}$ concentration is assumed. This appears to be true at least for the short term in ponrly buffered aquatic oyatems but does not hold for high alkalinity lakes. $\mathrm{Ca}$ concentration is used rather than alkalinity because of measurability and background data. The scatter in the original $\mathrm{Ca}$ concentration vs $\mathrm{pH}$ plot is mostly due to variable geological factors in the areas sampled and to seasonality and DIC equilibrium changes. An unquantified problem is the effect of Al on Ca.

The acidification calculation indicates that precipitation $\mathrm{pH}$ must be 4.6 or less to cause measurable acidification. There is some disagreement as to whether the theoretical unpolluted precipitation $\mathrm{pH}$ of 5.6 is ever found in the real world. D. Schindler suggests that either the $\mathrm{pH}$ of natural rain is less than 5.6 or most of the northern hemisphere has been acidified. 


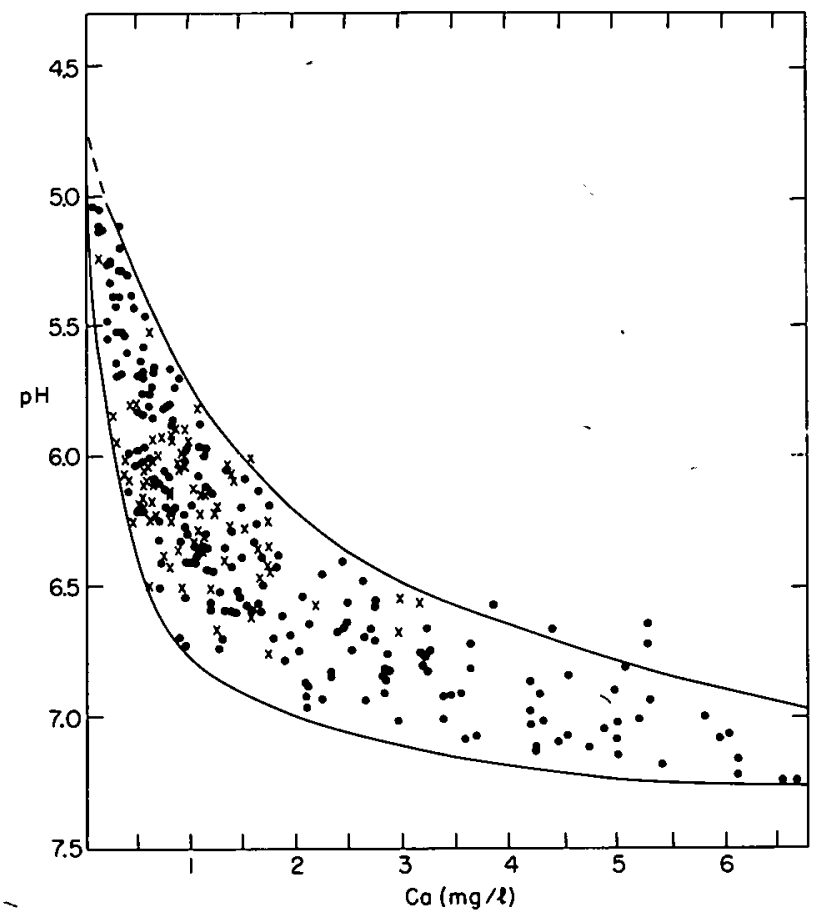

Figure 1. $\mathrm{pH}$ versus $\mathrm{Ca}$ concentrations observed in a large number of lakes in northern and northwestern Norway where impacts of acid precipitation are light or nonexistent. 
Session III

ALUMINUM CHEMISTRY IN DILUTE WATERS

C. Driscoll

\section{BACKGROUND}

A study to characterize the surface water chemistry in the Adirondack region of New York took place from August 1977 to August 1978. The three principal study lakes were:

$\begin{array}{ll}\text { Big Moose Lake } & \mathrm{pH}<5 \\ \text { North Lake } & \mathrm{pH}<5 \\ \text { Littlø Moo6e Lake } & \mathrm{pH}>7\end{array}$

These lakes and their major tributaries (24 sites) were sampled at threeweek intervals during the spring, summer, and fall, and at four-week intervals during the winter. Samples were analyzed for calcium, magnesium, sodium, potassium, iron, aluminum, total organic carbon, sulfate, free fluoride, conductivity, alkalinity, and $\mathrm{pH}$.

In1tial results and background data (Schofield, 1976) indicated that aluminum levels in these acid waters were quite high $(0.2$ to $1.0 \mathrm{mg} / \mathrm{l})$. For this reason and because of the increased interest in aluminum toxicity to aquatic fauna, particularly fish populations, a substantial portion of this investigation involved aluminum chemistry.

\section{ALUMINUM FRACTIONATION METHODS}

The basic method selected for the study was the ferron-orthophenanthroline colorimeteric technique (Rainwater and Thatcher, 1960). Advantages of this method are that: (1) it may be modified to measure monomerir aluminum, (2) It has been used successfully in the past by a number of investigators, and (3) the procedure is simple, allowing many samples to be processed quickly.

However, fluoride and iron interfere with measurements by this method. Fluoride levels are low in these waters and the interference is undetectable. Iron interference is generally low ( $0.06 \mathrm{mg} \mathrm{Al} / \mathrm{mg} \mathrm{Fe}$ ) but should be corrected for as suggested by Rainwater and Thatcher (1960). The levels of iron encountered in this study were generally less than $0.05 \mathrm{mg} / \mathrm{l} \mathrm{Fe}$.

Three forms of aluminum were determined in this study: (1) Alr = acid reactive aluminum which approximates total aluminum (Rainwater and Thatcher, 1960; Hem and Robertson, 1967); samples were acid digested for thirty minutes prior to analysis. (2) $\mathrm{Ala}=$ total monomeric aluminum; analysis done without acid digestion (Smith, 1971; Smith and Hem, 1972). And (3) Alo = cation desalted aluminum, samples were passed through a strongly acidic cation exchange resin (Amberlite 120, largely in the sodium cycle, effluent $\mathrm{pH} 5.0$ ), and were then measured as monomeric aluminum.

It is possible to manipulate these measurements of aluminum to obtain estimates of aluminum fractions: (1) Alo = an estimate of organically complexed aluminum. (2) Ala - Alo = an estimate of inorganic monomeric aluminum; this would include free aluminum and aluminum complexes with hydroxide, 
fluoride, and sulfate. And (3) Alr - Ala = an estimate of acid soluble aluminum; this would include colloidal aluminum, polymeric aluminum, and strongly complexed organic aluminum.

In dilute waters, free aluminum and aluminum complexed with inorganic ligands are predominately cationically charged. These species are, therefore, readily removed by polar cation exchange resins. It is presumed that organic matter and organically complexed aluminum would be anionically or nonionically charged and would pass through a cation exchange column. Three sources of evidence suggest that this assumption is reasonably valid: (1) almost no change in organic carbon measurements of samples passing through the cation exchange column was observed; (2) no discernible change occurred in ultra violet (200 to $400 \mathrm{~nm}$ ) spectral pattern between cation exchange column influent and effluent; and ( 3 ) cation desalted aluminum measurements equal total monomeric aluminum measurements for summer stream water data during lowflow high $\mathrm{pH}$ conditions.

There are a number of sources of error in this type of measurement of organically chelated aluminum. The resin may pull weakly complexed aluminum away from organic ligands; alumino-organic complexes may exchange or absorb on resin sites; or if the resin $\mathrm{pH}$ is low, organic material may precipitate in the resin bed. These sources of error will tend to underestimate the organically chelated fraction of aluminum.

Monomeric inorganic aluminum ( $\mathrm{Ala}$ - $\mathrm{Alo}$ ) may be further subdivided, using ligand concentration data and thermodynamic equilibrium constants into free aluminum and aluminum fluoride, hydroxide, and sulfate complexes. Chemical equilibrium must be assumed for this analysis, but this assumption may be reasonable for aqueous. phases.

\section{DISCUSSION OF ALUMINUM FRACTIONATION- TECHNIQUES}

D. Schindler stated that in his expérience anion exchange resins removed about $80 \%$ of organic matter and catton exchange resins removed about $20 \%$ of organic matter.

The degree to which organic material is removed by resins is extremely dependent on the chemical nature of the resin, the $\mathrm{pH}$ of the resin, and the chemical nature of the organic material. Therefore, it is difficult to compare results of different investigators in this regard.

The difficulty in evaluating alumino-organic complexes stems from the fact that it is difficult to partition organically chelated aluminum from inorganically complexed aluminum. Because of the chemical nature of aluminum, conventional tools such as ion selective electrodes and anodic stripping voltammetry are of little use.

Experiments by $M$. Johannessen indicated that ultrafiltration is not a feasible approach for partitioning aluminum. Aluminum apparently precipitates or absorbs at the ultrafiltration membrane surface; aluminum would not pass through the membrane, even at low $\mathrm{pH}$ values. Ultrafiltration for copper and iron appeared to be satisfactory. It was suggested that isoelectrical techniques like those developed by Soviet scientists should be applied to humic substances to determine their charge.

W. Dickson fractionates aluminum by total aluminum and filterable aluminum. 


\section{ALUMINUM FRACTIONATION AND SPECIATION \\ EXAMPLES OF RESULTS FROM ADIRONDACK WATER ANALYSIS}

Regression of the negative logarithm of the metal concentration ( $\mathrm{pM}$ ) as a function of $\mathrm{pH}$ was performed for all 24 sampling sites for a single sampling period (Figure 1). Basic cation ( $\mathrm{Ca}, \mathrm{Mg}, \mathrm{K}, \mathrm{Na}$ ) levels increase with increasing $\mathrm{pH}$. Aluminum however decreases with increasing $\mathrm{pH}$.

Temporal data for acid reactive aluminum (Alr) were collected at three sites (Figure 2), $\mathrm{NL} 6(\mathrm{pH} 4.1$ to 4.5 ) and $\mathrm{NL} 12$ ( $\mathrm{pH} 4.6$ to 7.2) which are tributaries to North Lake, and LM 1 which is a lake surface water sample from Little Moose Lake $(\mathrm{pH}>7)$. Note that aluminum levels are highest in the low $\mathrm{pH}$ samples. Also, aluminum increases during periods of high tributary discharge (heavy rains in late August and late September and snowmelt from late March through early May).

Aluminum fractionation data were obtalned for tribulary NL 12 (Figure 3). In all samples, Alo correlates well with TOC. In the tributaries TOC is high in the fall and summer and low in the winter. The Ala in NL 12 follows this pattern. Inorganic monomeric aluminum (Ala - Alo) peaks in tributaries during periods of high discharge (late summer, fall, and snowmelt). During the summer dry season it is essentially zero.

Aluminum fractions were also obtained for Big Moose Lake samples (Figure 4). Alo again is closely correlated with TOC. Ala is high during the winter and low in the summer and fall. Inorganic monomeric aluminum (Ala - Alo) is greater in relative magnitude than in tributary samples. This fraction of aluminum shows no seasonal trends in lake samples, but $\mathrm{pH}$ is more constant in lakes than in tributaries. The acid soluble aluminum (Alr - Ala) is approximately constant seasonally in both lakes and tributaries.

Trends in monomeric aluminum species determined for Adirondack water samples indicate that the bulk of the aluminum is generally complexed with organic matter (Figure 5). Inorganic monomeric aluminum is dominated by aluminum fluoride complexes. Although fluoride levels in these waters are low, the fluoride ligand has a very strong affinity toward the aluminum cation. As a result, a significant fraction of the aluminum is complexed by fluoride. Free aluminum and aluminum hydroxide complexes exist but are of less importance. Sulfate levels are generally low ( $\left.<10 \mathrm{mg} / \ell \mathrm{SO}_{4}\right)$ and aluminum sulfate complexes are insignificant. Only the aluminum hydroxide complexes have the ability to neutralize hydrogen ion and contribute to the acid neutralizing capacity of a water. These complexes make up only a small fraction of the total aluminum in the water.

The alumino-organic complexes appear to be stable over a relarıvely wide $\mathrm{pH}$ range. By altering the $\mathrm{pH}$ of the sample, the maximum cation desalted aluminum (A10) occurred at about $\mathrm{pH}$ 5. At $\mathrm{pH} 3$ and $\mathrm{pH} 6.5$, Alo was reduced by about $20 \%$.

The following hypothesis for aluminum mobilization was proposed. During the soil podzolization process, aluminum is mobilized by organic acids. Some of these are released to the environment as organically complexed aluminum and some are precipitated out in the lower soil profiles as aluminum organics and amorphous aluminum. During periods of ralnfall and snowmelt, these amorphous aluminum forms are readily solubilized by strong mineral acids and released to the surface water, generally as inorganic aluminum (Ala-Alo). Quite possibly, aluminum is the most readily mobilized component during periods of high discharge. Calcium, silicic acid, and other components exist in these soils 
primarily as crystalline substances (e.g., feldspars and nicas). These minerals are not readily dissolved in the presence of dilute strong acids, and during periods of high discharge these components show a dilution effect. Silicic acid does not readily precipitate into the soil profile; it therefore is gradually leached from soil.

\section{DISCUSSION OF ALUMINUM CHEMISTRY IN DILUTE WATERS}

J. Kramer noted that crushed feldspar is very reactive. However, surface precipitates of aluminum and silicon could form on feldspars and inhibit dissolution. Under these circumstances increased mobilization of silicon would be expected (along with aluminum) during increased discharge periods. Silicon, however, may not be leached as rapidly as aluminum because its dissolution is not as $\mathrm{pH}$ sensitive.

C. Driscoll conducted an experiment utilizing lake water and sediment held at $\mathrm{pH}$ 4. The results indicated a rapid and large initial leaching of aluminum from the sediment into the water column and then a lesser linear increase in aluminum concentration in the water with time. Dissolved silica concentrations increased at a slow linear rate suggesting dissolution of the crystalline phase rather than dissolution of amorphous material on desorption.

G. Likens noted the same results for sediments from Hubbard Brook.

$\mathrm{J}$. Kramer indicated that these sediments may reflect only the environment from which they are derived (i.e., lake or'stream bottom), and the results may not be valid for soil-water interfaces.

C. Driscoll noted that lake sediments are probably not in equilibrium with the water. Passage of lake water through sediments elevates the $\mathrm{pH}$ significantly. $\mathrm{pH}$ of sediments in Big Moose Lake and North Lake ranged from 4.6 to 6.2 .

J. Galloway noted in Woods Lake, that $\mathrm{pH}$ of the interstitial water is about 4.7. At a depth of 5 to $6 \mathrm{~cm}, \mathrm{pH}$ is about 5; with increasing depth, the $\mathrm{pH}$ starts to climb to about 6 .

C. Driscoll indicated that when the aluminum-organic complexes enter the lake, organic material is degraded. This will release aluminum and result in supersaturation and possibly precipitation of aluminum. Free aluminum in Big Moose and North Lakes appears to be supersaturated with respect to kaolinite and gibbsite but slightly undersaturated with respect to amorphous aluminum.

J. Galloway suggested that aluminum levels in sediment cores could be used as a tracer of acidification. During the first stages of acidification, aluminum would be mobilized out of the soils but the lake would not yet be acidified. Therefore, large quantities of aluminum would precipitate and accumulate in lake sediments. As the lake $\mathrm{pH}$ decreases with increased acidification, resolubilization of aluminum from sediments may occur and aluminum levels in the sediments may decline.

C. Driscoll noted that aluminum deposition in a lake would depend on the kinetics of aluminum precipitation which would depend on the availability of sites for nucleation of aluminum precipitation. If the availability of sites is a function of transparency, then in lakes with high transparency the kinetics of precipitation may be slow and aluminum would be oversaturated.

C. Driscoll stated that x-ray diffraction analysis of sediments from Big Moose and North Lake revealed feldspars and micas but no gibbsite or clay.

$J$. Kramer indicated that a crystalline structure must account for about $5 \%$ of the substance for it to be detectable in $x$-ray diffraction analysis. 
Therefore, the inability to detect gibbsite with $x$-ray diffraction does not mean that it is not present. Gibbsite may also form a coating on feldspars and this would not be detected in $x$-ray diffraction analysis.

A final point in the discussion involved the possible role of aluminum in oligotrophication of acid lakes. As aluminum precipitates, it probably simultaneously scavenges phosphate and sulfate out of solution.

W. Dickson discussed laboratory results involving natural waters with orthophosphate addition. Orthophosphate was added to lake water (both highly humic waters and waters with high inorganic aluminum levels) and let stand for one week. In humic waters, almost all the phosphate added could be recovered in the water. In acid waters with aluminum, large decreases in dissolved phosphate occurred. A sharp reduction in the orthophosphate content of the waters occurred at $\mathrm{pH}$ values between 4.5 and 6.0 . At lower $\mathrm{pH}$ levels the phosphate was remobilized.

\section{REFERENCES}

Hem, J.D. and Robertson, C.E., Form and Stability of Aluminum Hydroxide Complereo in Dilute Eolutions, U.3. Geul. Buivey Waler Supply Paper 1827-A, 1967.

Rainwater, F.H. and Thatcher, L.L., Methods for Collection and Analysis of Water Samples, U.S. Geol. Survey Water Supp1y Paper 1454, 1960.

Schofield, C. Personal Communication, 1976.

Smith, R.W. Relations Among Equilibrium and Non-equilibrium Aqueous Species of Aluminum Hydroxy Complexes, In: American Chemical Society Advances in Chemistry Series, Vol. 106, 1971.

Smith R.W. and Hem, J.D., Effect of Aging on Aluminum Hydroxide Complexes in Dilute Aqueous Solution, U.S. Geol. Survey Water Supply Paper 1827-D, 1972 . 


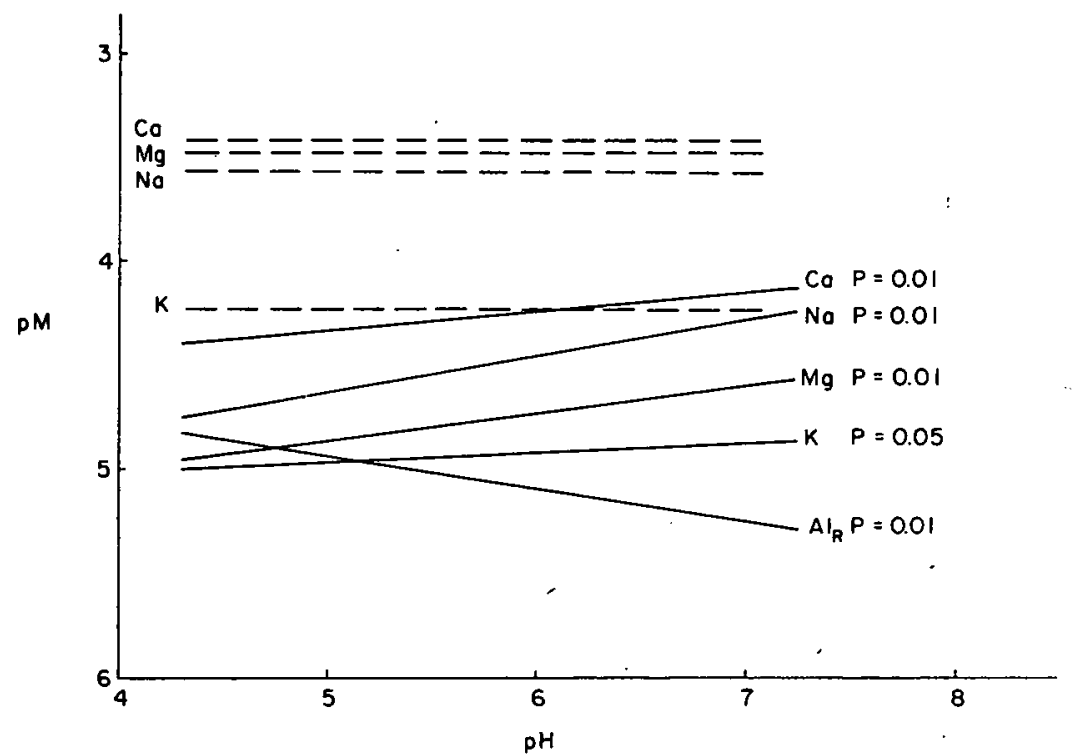

Figure 1. Regressions of the negative log on metal concentrations (pM) as a function of $\mathrm{pH}$ for 24 sampling sites for a single sampling period.

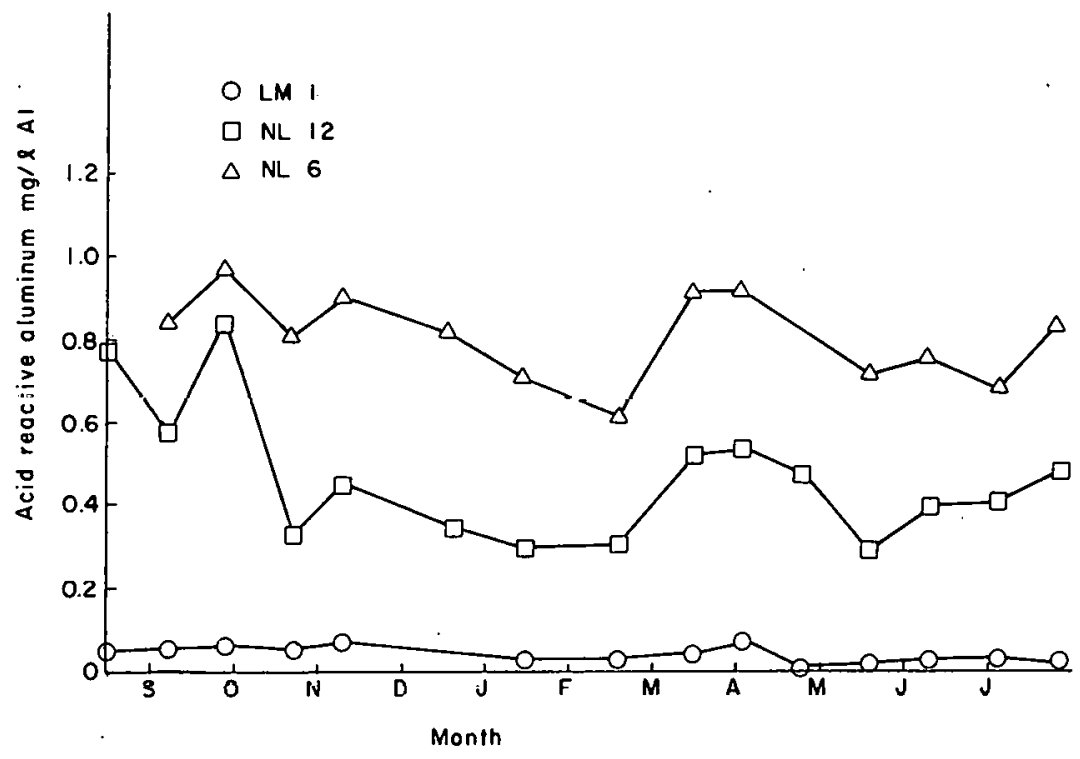

Figure 2. Changes in the concentrations of acid reactive aluminum (Alr) over time in months, at sites NL6, NL 12, and LM 1. 

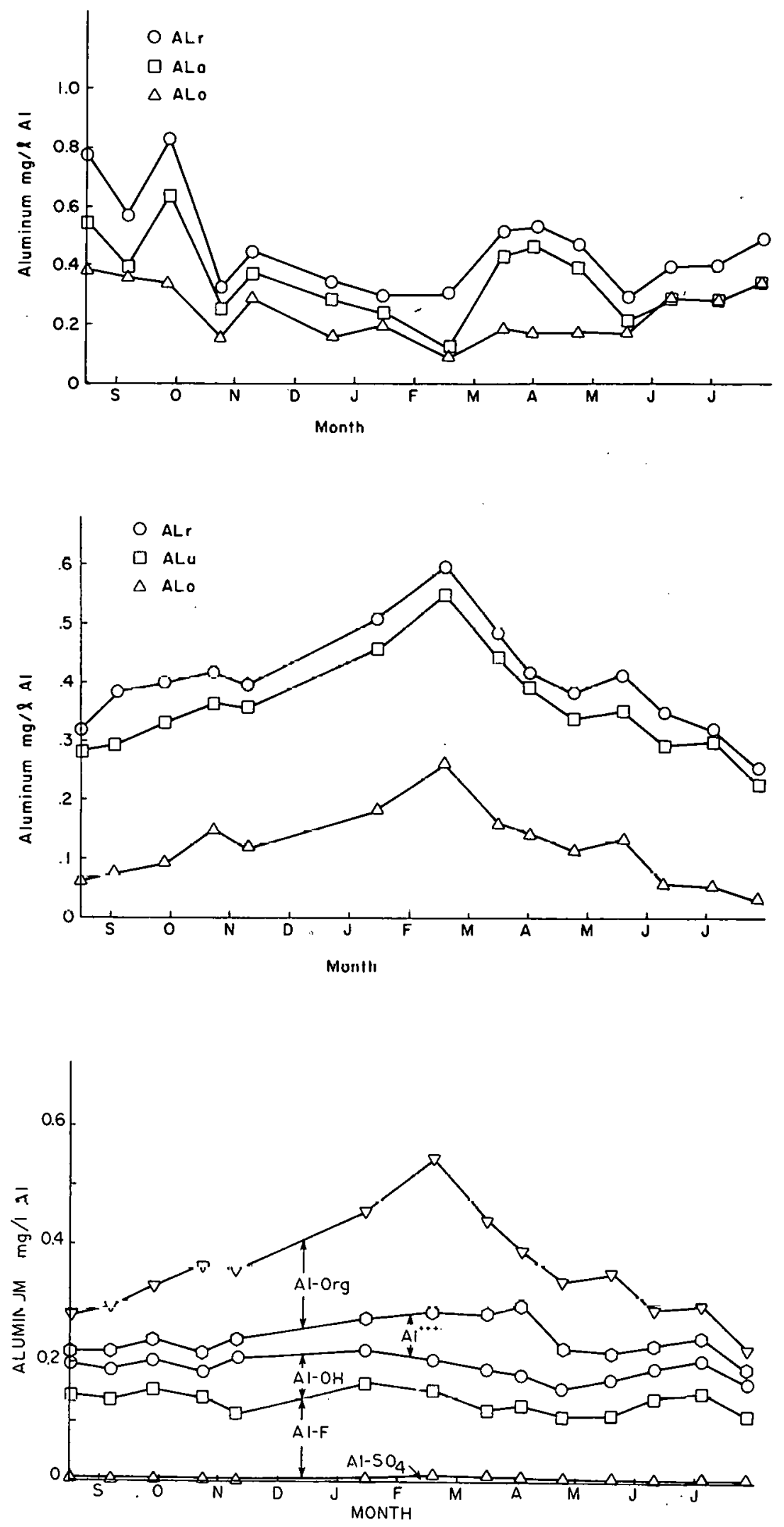

Figure 3. Variations in concentrations of aluminum fractions observed at site NL 12 over time.

Figure 4. Variations in concentrations of aluminum fractions obocrved at Big Moozc Lake over time.

Figure 5. Trends in monomeric aluminum species determined for Adirondack water samples. 
Session IV

CHEMICAL BUDGETS AND WATERSHED ACIDIFICATION

D. Schindler

Work is being conducted in the Experimental Lakes Area, located in the Precambrian Shelf, upwind of Sudbury. The ELA mission is to pick out aspects of lake pollution problems which one can study by manipulating lakes. These are usually problems which are difficult to study by means of observation on impacted systems or in the laboratory. One lake in particular is being studied by direct addition of $\mathrm{H}_{2} \mathrm{SO}_{4}$ to the lake. This method, therefore, is ignoring the terrestrial effects of acidification.

\section{LAKE CIRCULATION AND SEDIMENTS}

Full lake circulation does not occur in the spring because the lake basin is somewhat protected from wind by the surrounding forest, and because the surface warms very quickly. Winter $\mathrm{O}_{2}$ deficits are held over in hypolimnion and anoxic conditions occur, even though the lake is oligotrophic. Sands of sediments are noncalcareous and have high iron contents.

\section{RESULTS OF ACIDIFICATION}

In 1976 no $\mathrm{pH}$ drop was observed although the $\mathrm{HCO}_{3}$ concentration decreased. In $1977 \mathrm{pH}$ was lowered to 6 and held at this level. Theoretical pH and alkalinity for a bicarbonate system were compared to observed results.

1. Assumed the lake degassed the 1 lost $\mathrm{CO}_{2}$ to the atmosphere.

2. Efficiency of reducing $\mathrm{HCO}_{3}$ was $47 \%$ in 1976 and $41 \%$ in 1977 .

A progressive increase in the length of the anoxic period occurred during fertilization. In an anoxic hypolimnion, sulfate is reduced to sulfide by bacteria.

DIC decreased in epilimnion over the two-year acidification from 100 to $10 \mu \mathrm{M}$. However, the deep-water DIC concentrations were not affected. This phenomenon was probably due to $\mathrm{SO}_{4}^{-2}$ reduction:

a. 1 mole of sulfate +1 mole sulfide +2 moles DIC.

b. The DIC is produced as $\mathrm{HCO}_{3}{ }^{-}$to provide charge balancetor $\mathrm{Fe}^{+2}$ liberated by anoxic hypolimnion sediments.

Addition of $\mathrm{H}_{2} \mathrm{SO}_{4}$ to the lake increases $\mathrm{SO}_{4}^{-2}$ reduction and therefore increases buffering capacity. High iron concentrations are partly due to $\mathrm{Fe}^{+2}$ $\rightarrow \mathrm{Fe}(\mathrm{OH})_{3}$ at the thermocline, which reprecipitates, keeping iron trapped in the hypolimnion.

Methane production increases as sulfate becomes totally reduced. An important conclusion is that the lake's biology (sulfate reduction) contributes to buffering. 
Q. Did you get sulfate reduction in acidified corrals?

A. There is some sulfate loss, but it may be due to water loss.

Q. Where could missing sulfate go?

A. Sulfate reduction and $\mathrm{FeS}$ precipitation in surface sediments is a possibility.

Q. Will sulfate reduction occur in nonstratified lakes?

A. Possibly, if reduction occurs in surface sediments. But lakes in Norway have complete spring and fall turnover, so not much sulfate reduction occurs.

Q. What about zinc, aluminum, and manganese concentrations?

A. Zinc concentrations lcvelcd off at $300 \mu \mathrm{g} \quad \ell^{-1}$ at $\mathrm{pH}$ 5. Aluminum was between 20 and $30 \mathrm{\mu g} / \ell$. Manganese and 1ron were mobilizèd tó sómé degree. In the water column, cobalt and iron are in particulate matter al $p H$ 6.7, whlle lley ase lil dissulved malter al $p H$ j. Therefore, a metal and its path through the food chain can be affected by $\mathrm{pH}$.

Q. What are the short-term and long-term benefits of whole watershed studies?

A. Short-term effects include the effects seen of buffering by sulfate reduction, the atmosphere-water system can't be simulated, and the pollution input-out can be precisely calculated. It also may be possible to see elevated metal concentrations. However, these may not be the same in the long-term effects because of water renewal. Long-term studies are therefore essential. We should do the same (studies) with the terrestrial system.

Q. How would you spray srowpack or watershed area to simulate acidification? You must cover entire canopy.

A. Maybe acidify snowpack in a "clean" area (with snow machine) and study snowmelt effect.

Q. Would this buffering (due to sulfate reduction) occur in lakes which aren't high in iron concentration?

A. 'Ihere would have to be some cation like iron to balance bicarbonate.

Q. What might be advantages to watershed use to understand acidification?

A. No hydrogen ion contents were seen in the outflow, so the lake has a nearly perfect hydrogen ion retention. Watersheds may buffer the effects of hydrogen ions.

At this point it was concluded that watershed $\mathrm{H}^{+}$retention was based largely on soil lysimeter, lake area versus watershed area, and leaching studies. 


$$
\text { Session V - A }
$$

BENTHIC ORGANISMS

H. Hultberg

'Projects on acidification and liming are carried out in six Swedish lakes, with $\mathrm{pH}$ values in the range 3.8 to 5.2 before liming.

\section{BENTHIC MACROPHYTES}

Terrestrial Sphagnum spp. was found to form mats on bottoms of clear acid lakes, but only in shallow areas in humic lakes. During the process of acidification of Lake Orvattnet between 1967 and 1977, a general increase of Sphagnum is especially apparent in the $0-$ to $2-\mathrm{m}$ and 4 to $6 \mathrm{~m}$ depths. In the 0- to 2-m depth in shaded areas the increase of bottom areas covered with Sphagnum spp. was from 6 to $60 \%$ during this period. In unshaded shallow areas, no apparent increase occurred during the same period. The general trend in the deeper areas is that Sphagnum spp. increase with increased acidity. The common species Isoetes sp. and Lobelia sp. are overgrown and disappear in some areas.

\section{BENTHIC ALGAE}

Benthic algae (Mougeotia sp. Batrachospermum sp. etc) increase rapidly and form a benthic "felt" together with dead organic matter, Sphagnum, Carex spp., Nymphaea sp., etc. and fungal hyphae. The "felt" has been observed down to $8 \mathrm{~m} \mathrm{depth}$. Both the "felt" and the Sphagnum mat effectively cover the bottom sediment and thus produce both a chemical and a biological effect.

\section{BENTHIC INVERTEBRATES}

Sampling in acid lakes, and in acid lakes before and after liming, has shown the dynamics of species composition and benthic biomass to be different in acidified lakes. In deeper areas, $>5 \mathrm{~m}$, chironomids dominate in both number and biomass in acid lakes. By comparing different lakes with increasing acidity in the range $\mathrm{pH} 6.2$ to 4.2 , the biomass of chironomids, and thus the total biomass, at first decreases and then increases to high values in the most acid lakes. The same change appears when liming a very acid lake - the biomass decreases during the first years and then slowly starts to increase again. Several species of bivalves, gastropods, and crustaceans disappear while odonata, corixidae, and cronomidae among the Diptera change and/or increase in both species number and biomass. When fish are restocked most species of Corixidae and Odonata, which are sensitive to predation, become less important. The reintroduction of gastropods and crustaceans in limed lakes has been successful and some species now appear frequently after four years and often dominate in the fish diet.

In the lake Vastra Skälsjön old data (1943) of the composition and biomass of these species have been compared with data obtained in 1973, using the same type of equipment and sampling technique. Five species of chironomids found in great numbers in 1943 could not be found in 1973 . On the 
other: hand three species found in 1973 were not found in 1943. In 1943 Pseudochironomus sp., Stictochironomus sp., Tanytarsus sp., and Procladius sp., and in 1973 Limnochironomus sp., Microtendipes spp., Stictochironomus sp., and Micropsectra sp. were dominating. The gastropod Valvata sp. and the ephemerid Ephemera sp. had disappeared since 1943.

\section{DISCUSSION}

Acidification has caused an increase in clarity of the lake water and Sphagnum mats exist down to $10 \mathrm{~m}$ depth. The invasion of Sphagnum into the lake bottoms is mainly caused by the change in abiotic factors. The main carbon source utilized by Sphagnum is carbon dioxide which increases with increased acidification. The possibility of increased Al being important to Sphagnum growth was discussed.

The chemical microenvironment around the Sphagnum and "felt" mats is different from that of the rest of the lake. Reduced conditions occur beneath the mats with associated release of $\mathrm{N}_{2}, \mathrm{CO}_{2}, \mathrm{NH}_{4}$, and $\mathrm{H}_{2} \mathrm{~S}$.

Other macrophytes like Isoetes sp., Lobelia sp., Utricularia sp. are still present in acid lakes, though in places they were overgrown. Probably the primary production in the acid lake as a whole has increased because of this increased benthic biomass. 
Session V-B

INVERTEBRATES: QUALITY AND QUANTITY AS FISH FOOD

G. Raddum

The Laboratory for Freshwater Ecology and Inland Fisheries at the Zoological Museum, University of Bergen, is involved in the SNSF-project and other projects concerning animal life. in freshwater ecosystems. Synoptic studies of invertebrates are being carried out in about fifty oligotrophic lakes. The lakes are situated in the southwest and northwest parts of Norway. In the southwestern region we have acid rain and acid lakes, while this is not the case in the northwestern region. The aim of the investigation concerning acid rain is to get some general base information about the fauna in oligotrophic acid - and less acid lakes in areas with and without acid precipitation. The studies are both qualitative and quantitative and are to be used for:

1) base line investigations for future reference

2) comparative studies among lakes of similar water quality except for $\mathrm{pH}$.

Differences in the aquatic fauna among lakes with high and low $\mathrm{pH}$ will be pointed out and faunal changes over time may become apparent. In these lakes the $\mathrm{pH}$ varies from 6.5 to $4.3, \mathrm{Ca}{ }^{+}$from 0.5 to $3.0 \mathrm{mg} / 1$, and chlorophyll a is $<2 \mu \mathrm{g} / 1$. Lakes in areas with acid rain and high $\mathrm{pH}$ must necessarily have higher buffer capacity, reflected in some of the lakes with $\mathrm{Ca}$ contents up to $3 \mathrm{mg} / \mathrm{l}$. Preliminary data from about twenty of the lakes are now available.

The number of zooplankton species (Crustacea and Rotatoria) in vertical hauls from the deeper part of the lakes decreases as $\mathrm{H}^{+}$increase (Table 1 and Figure 1). This is most marked for the cladocerans which in many cases are reduced to a single species in the acid lakes, while reductions are less distinct for Copepoda and Rotatoria. A decrease in species number is not obvious in humic acid waters. This is important to note since humic acidwaters occur naturally, while clear acidwaters are unnatural.

The crustaceans are also analyzed with regard to the animals' function (filter and raptorial feeders, Figure 2). The species number of filterfeeders is strikingly reduced in clear-water acid lakes, but less so in the humic aeid lakes. The same sort of observations are made for the raptorial feeders, but the changes are not as obvious. The decrease in zooplankton species in clear-water acid lakes can not be explained by direct $\mathrm{H}^{+}$effects alone. One must also consider other chemical components in clear and humic acidwaters, problems of adaptation, food supply, and other aspects of the biotic environment in the different lake types.

Data on bottom animals also show reductions in species numbers with $\mathrm{H}^{+}$ increase. Figure 3 shows the situation for caddisflies. These data agree very well with earlier reports from SNSF-project on mayflies and stoneflies. The most common animal group, however, in freshwater are the chironomids. Species composition for these are not yet finished, but we have some quantitative data. Summer values for numbers of individuals and biomass are reduced in acid lakes (Figure 4) and the less acid lakes have a very distinct peak around the $2-\mathrm{m}$ depth that was not observed in the acid condition. Very similar patterns were observed during spring as well (data not shown). This is one of the most interesting and striking differences between the lakes. 
Acid episodes during snowmelt or heavy acid rainfall in autum have the strongest influence on the top water layers. Animals that live near the shore at $0.5-\mathrm{m}$ depth are adapted for stronger environmental stress than animals at 2-m depth. This may partly explain why the 2-m zone (with the highest biomass in less-acid lakes) seems to be most strongly affected by acid precipitation. Stream invertebrates also have been experimentally tested with regard to acid episodes. Organisms, substrate, and water from two rivers (high and low conductivity water) were put into aquaria. The $\mathrm{pH}$ was dropped to around 4.5 by addition of $\mathrm{H}_{2} \mathrm{SO}_{4}$. Reference aquaria had the natural water with $\mathrm{pH}$ about 6. 0 to 6.5. Water chemistry during the soft water experiment is- shown in Table 2. Various species of Ephemeroptera, Plecoptera, and Tricoptera were tested. After 5 days, about $75 \%$ of the living animals were picked out for caloric measurements. The remaining $25 \%$ were kept in the aquaria to continue the survival experiment. The mayflies (Baetis rhodani) died after 2 days in the acid soft water experiment while the survival was better in the water with higher conductivity.

Species such as Amphinemura sulcicollio (Figure 5) ludving decreased survival also had reduced caloric values in acid waters (Table 3). Other species were indifferent to acid stress and one species of Trichloptera had an increase in caloric value. Survival was better in the higher conductivity water, but the same trends as in the soft water experiment were also obvious in this case.

\section{DISCUSSION}

Davis has looked at maintenance of $\mathrm{Na}$ balance by various species under acid stress. Much more energy is needed to maintain the balance, and this may in part explain the lower caloric values observed by Raddum.

An increase in invertebrates is apparent in lakes when the fish population dies out and fish predation is removed. Such increases have been observed for corixids, larvae of odonats, and waterbeetles in acid lakes where the explanation seems to be reduced fish predation.

The apparent conflict between the Norwegian and Swedish data on invertebrate biomass is explained by the lower $\mathrm{pH}$ of the Swedish lakes. The Swed1sh data were also from a deeper part of the lake, but the data agree in the shallower areas. 
Table 1

Species Composition of Zooplankton in Acid and Less-Acid Lakes.

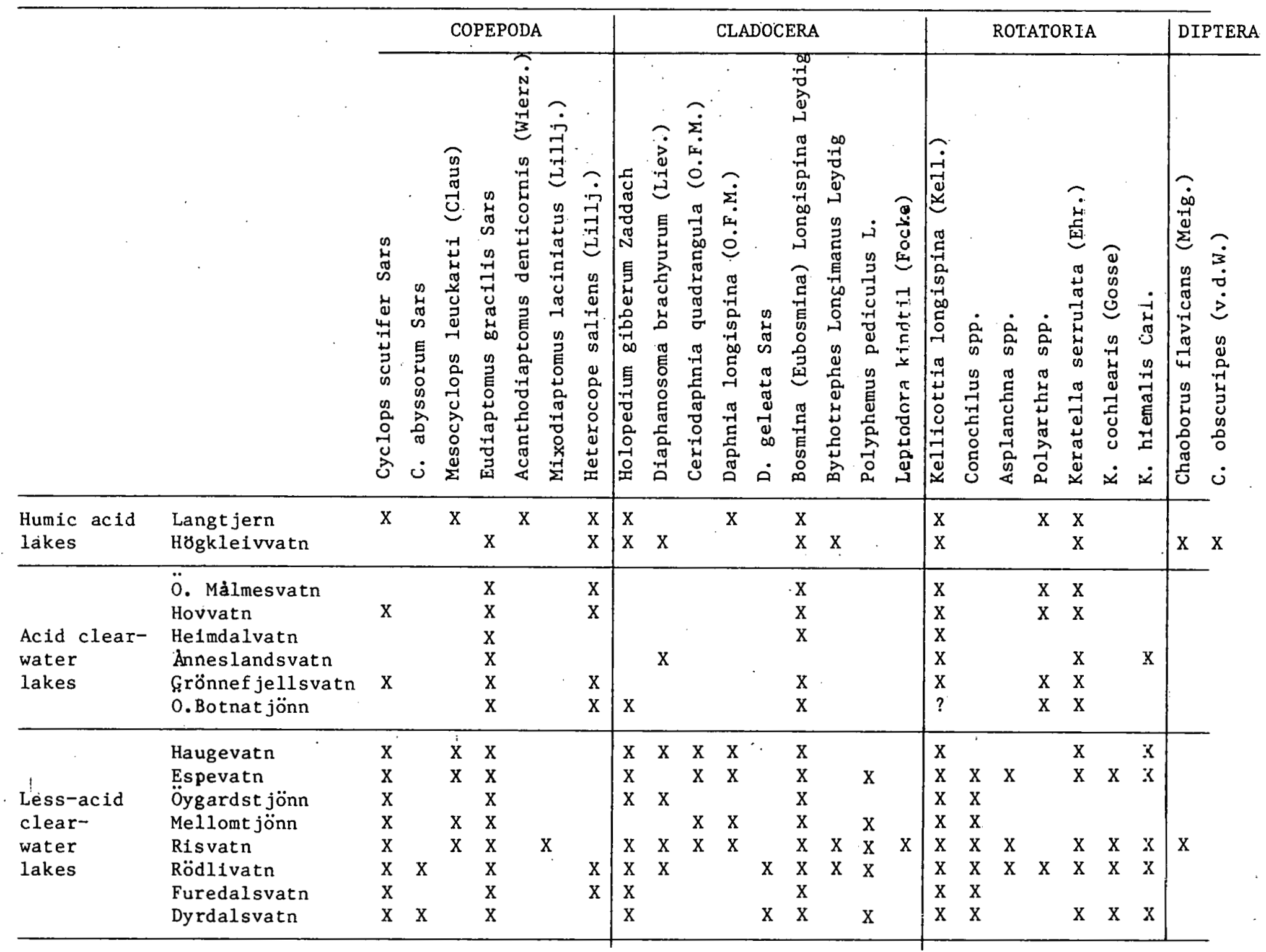


Table 2.

Water Chemistry in Aquaria 1 (Natural) and 2 (Natural $+\mathrm{H}_{2} \mathrm{SO}_{4}$ )

\begin{tabular}{|c|c|c|c|c|c|c|c|c|c|}
\hline & \multicolumn{9}{|c|}{$\mathrm{mg} / \mathrm{l}$} \\
\hline & $\mathrm{pH}$ & $\partial 20$ & $\mathrm{SO}_{4}$ & $\mathrm{NO}_{3}$ & $\mathrm{Mg}$ & $\mathrm{Ca}$ & $\bar{K}$ & $\mathrm{C} 1$ & $\mathrm{Na}$ \\
\hline $\begin{array}{l}\text { River water aquaria } \\
1 \text { and } 2 \text {, start }\end{array}$ & 5.9 & 32.8 & 3.38 & 145 & 0.56 & 1.18 & 0.66 & 6.4 & 3.75 \\
\hline Aquarium 1 after 7 days & 6.1 & 37.0 & - & - & - & - & - & - & - \\
\hline Aquarium 2 after $\%$ days & 4.75 & 52.0 & - & - & - & - & - & - & - \\
\hline Aquarium 1 after 14 days & 5.9 & 40.3 & 3.3 & 210 & 0.64 & 1.37 & 1.06 & 8.0 & 4.41 \\
\hline Aquarium 2 after 14 days & 4.87 & 67.5 & 14.1 & 150 & 0.83 & 2.24 & 1.63 & 8.4 & 4.55 \\
\hline
\end{tabular}

Table 3.

Measurement of the Caloric Values (cal $\mathrm{g}^{-1} \mathrm{dw}^{-1}$ ) in Insect

Larvae After 5 days in Aquaria with $\mathrm{pH} 4.5$ to 4.7 and $\mathrm{pH} 6.0$

\begin{tabular}{|c|c|c|c|c|c|}
\hline Species & $\mathrm{pH}$ & $\mathrm{n}_{\text {ind }}$ & $\mathrm{n}_{\mathrm{p}}$ & cal $\mathrm{g}^{-1}$ & $1 \mathrm{dw}^{-1}$ \\
\hline \multicolumn{6}{|l|}{ Plecoptera } \\
\hline $\begin{array}{l}\text { Brachyptcra risi } \\
\text { Amphinemura sulcicollis } \\
\text { Leuctra hippopus } \\
\text { Protonemura meyeri } \\
\text { " } \\
\text { Nemoura op. }\end{array}$ & $\begin{array}{l}4.7 \\
6.0 \\
4.7 \\
6.0 \\
4.7 \\
6.0 \\
4.7 \\
6.0 \\
6.0\end{array}$ & $\begin{array}{r}22 \\
53 \\
53 \\
58 \\
3 \\
6 \\
10 \\
5 \\
49\end{array}$ & $\begin{array}{l}3 \\
4 \\
2 \\
2 \\
1 \\
1 \\
2 \\
1 \\
2\end{array}$ & $\begin{array}{l}4.085 \\
5.227 \\
4.586 \\
5.4805 \\
4.607 \\
5.246 \\
4.179 \\
4.070 \\
5.9305\end{array}$ & $\begin{array}{l} \pm 0.729 \\
+0.1026 \\
\mp 0.062 \\
\pm 0.091 .\end{array}$ \\
\hline \multicolumn{6}{|l|}{ Trichoptera } \\
\hline $\begin{array}{l}\text { Rliyacophila nubila } \\
\text { Polycentropus flavomaculatis } \\
\text { " } \\
\text { Plectrocnemia conspersa } \\
\text { " } \\
\text { Stenophylax lateralis }\end{array}$ & $\begin{array}{l}4.7 \\
6.0 \\
4.7 \\
6.0 \\
4.7 \\
6.0 \\
4.7\end{array}$ & $\begin{array}{r}6 \\
3 \\
16 \\
9 \\
2 \\
1 \\
8\end{array}$ & $\begin{array}{l}4 \\
2 \\
4 \\
3 \\
3 \\
1 \\
6\end{array}$ & $\begin{array}{l}5.789 \\
6.070 \\
6.0777 \\
5.033 \\
5.200 \\
5.319 \\
4.309\end{array}$ & $\begin{array}{l}+0.4155 \\
\pm 0.203 \\
\pm 0.0612 \\
\pm 0.859 \\
\pm 0.5247 \\
\pm 0.658\end{array}$ \\
\hline $\begin{array}{l}\text { Ephemeroptera } \\
\text { Leptophelbia vespertina } \\
\text { Baetis rhodani }\end{array}$ & $\begin{array}{l}4.7 \\
6.0\end{array}$ & $\begin{array}{r}10 \\
6\end{array}$ & $\begin{array}{l}1 \\
1\end{array}$ & $\begin{array}{l}5.604 \\
5.903\end{array}$ & \\
\hline
\end{tabular}




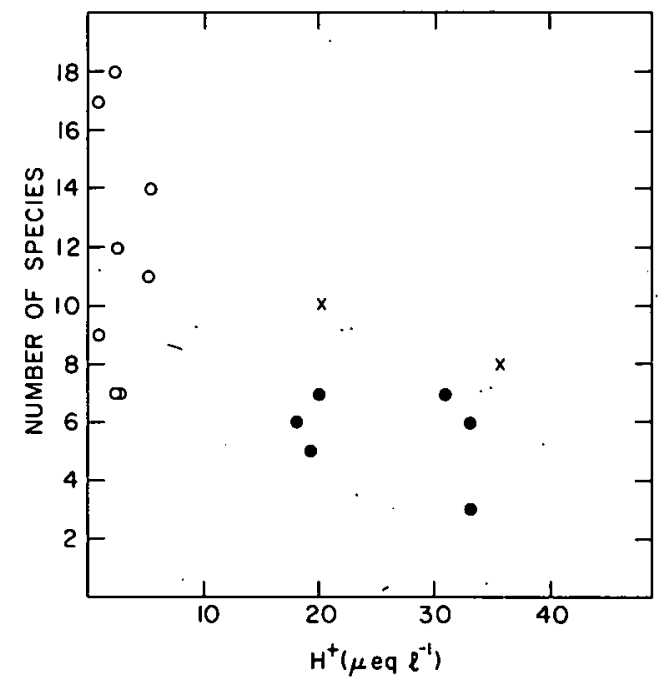

Figure 1(a). Tota1: Number of Zooplankton Species

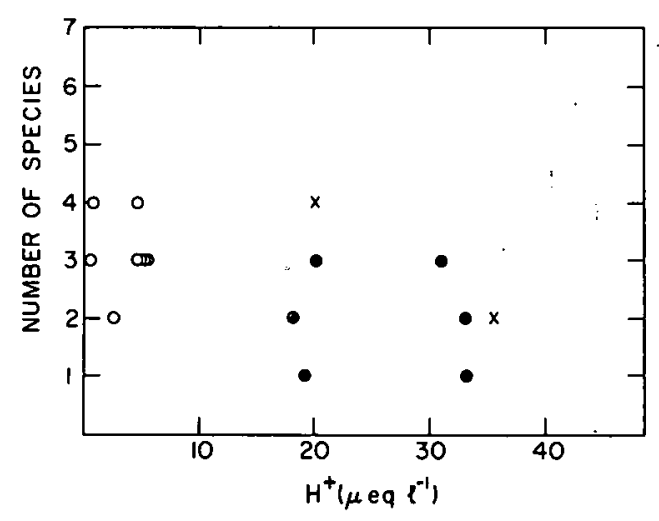

Figure 1(c). Copepoda

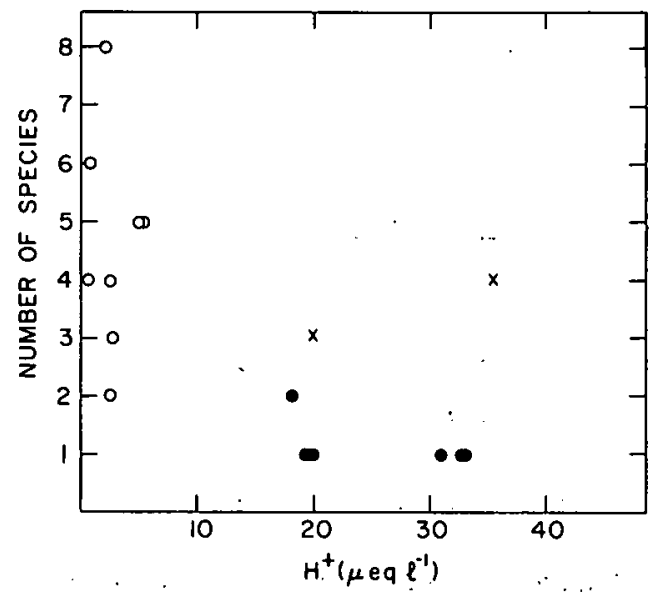

Figure $1(\mathrm{~b})$. Cladocera

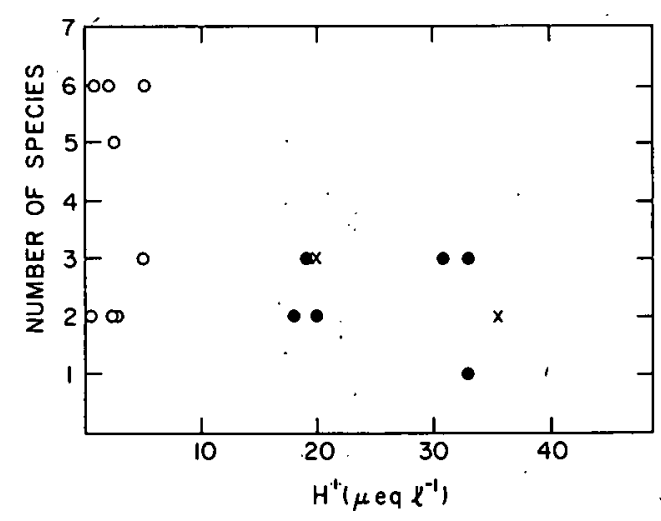

Figure 1(d). Rotatoria

Figure 1. Relationships between zooplankton species and concentrations of $\mathrm{H}+$ in less-acid, clear-water lakes (o), acid, clear-water lakes $(\bullet)$, and humic acid, lakes (x). 


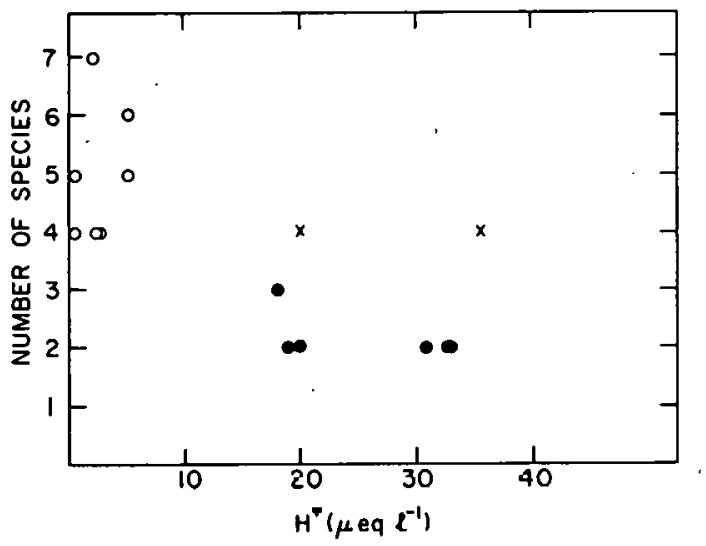

Figure 2(a). Filter Feeders

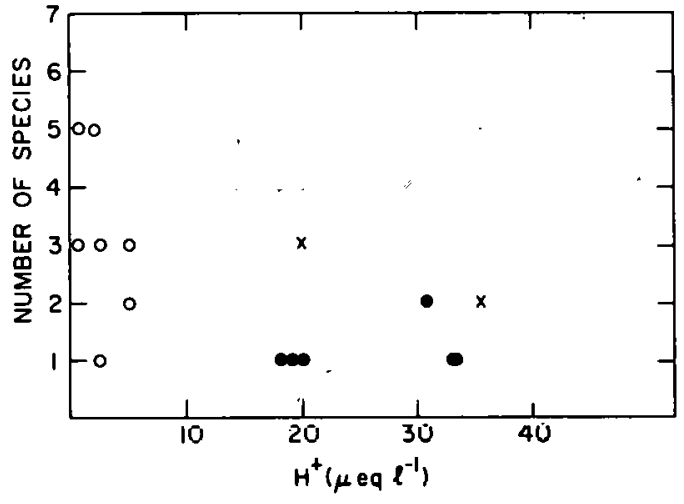

Figure 2(b). Raptorial Feeders

F1gure 2. Relationships between numbers of species of filter-feeders (a) and raptora1, feeders (b), and the concentrations of $\mathrm{H}+$ in lessacid, clear-water lakes (o), acid, clear-water lakes $(\bullet)$, and humic acid lakes $(\mathrm{x})$.

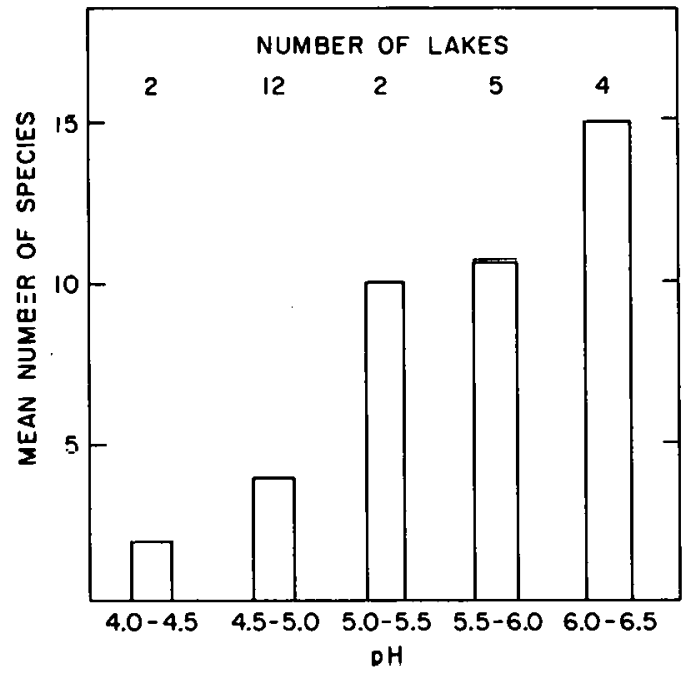

Figure 3. Mean numbers of caddistly species in lakes with different $\mathrm{pH}$, grouped into intervals of $1 / 2 \mathrm{pH}$ unit. 


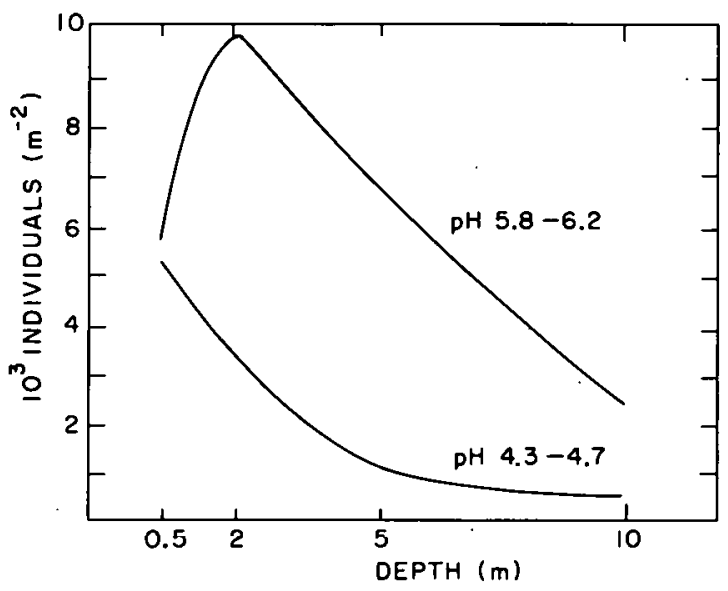

Figure 4(a). Chironomids

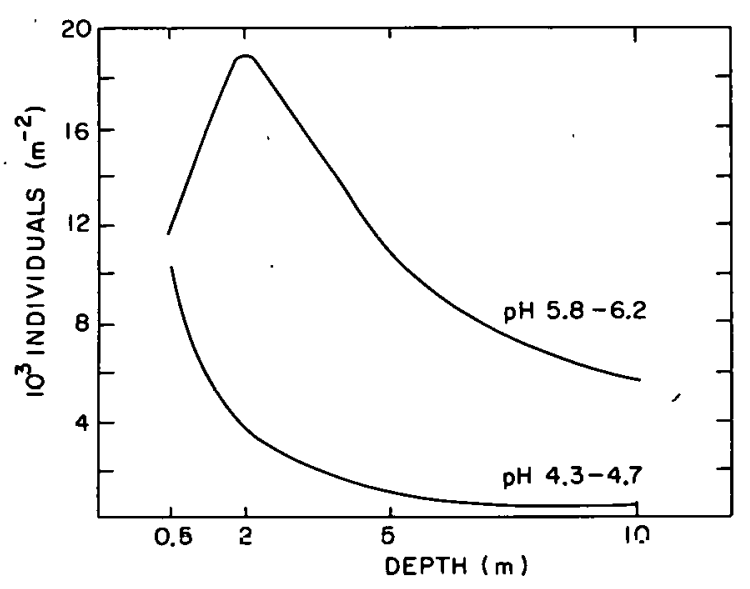

Figure $4(\mathrm{c})$ : Invertebrates

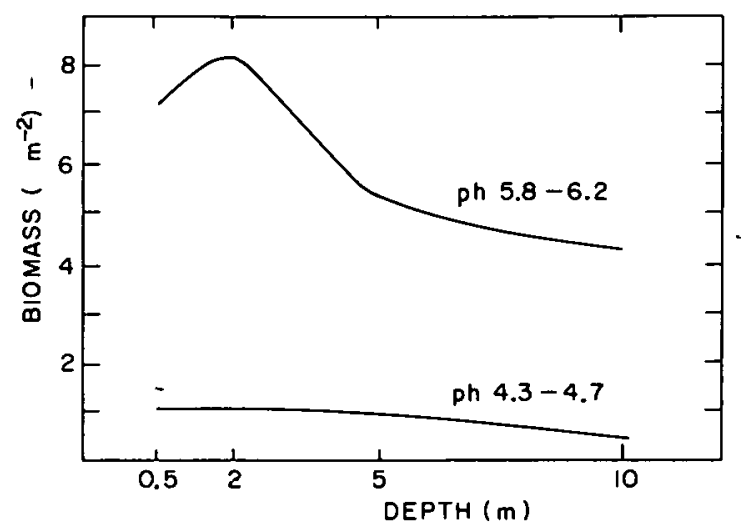

Figure 4(b). Chironomids

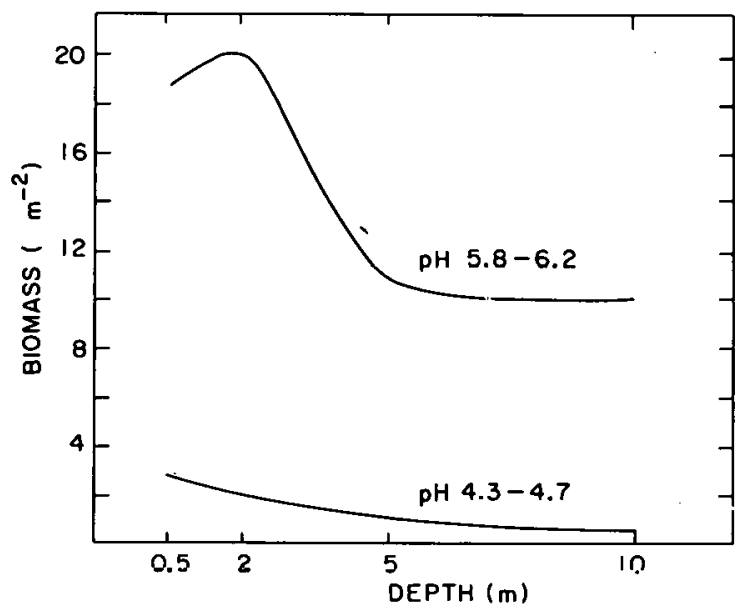

Figure 4(d). Invertebrates

Figure 4. Mean numbers of chironomld individuals (a) and their mean standing crops (b), and mean numbers of all benthic invertebrates (c) and their mean standing crops (d), observed in July 1977. Samples were all collected at 4 depth zones, from 5 lakes in the $\mathrm{pH}$ range 5.8 to 6.2 , and from 3 lakes in the $\mathrm{pH}$ range 4.3 to 4.7 . 


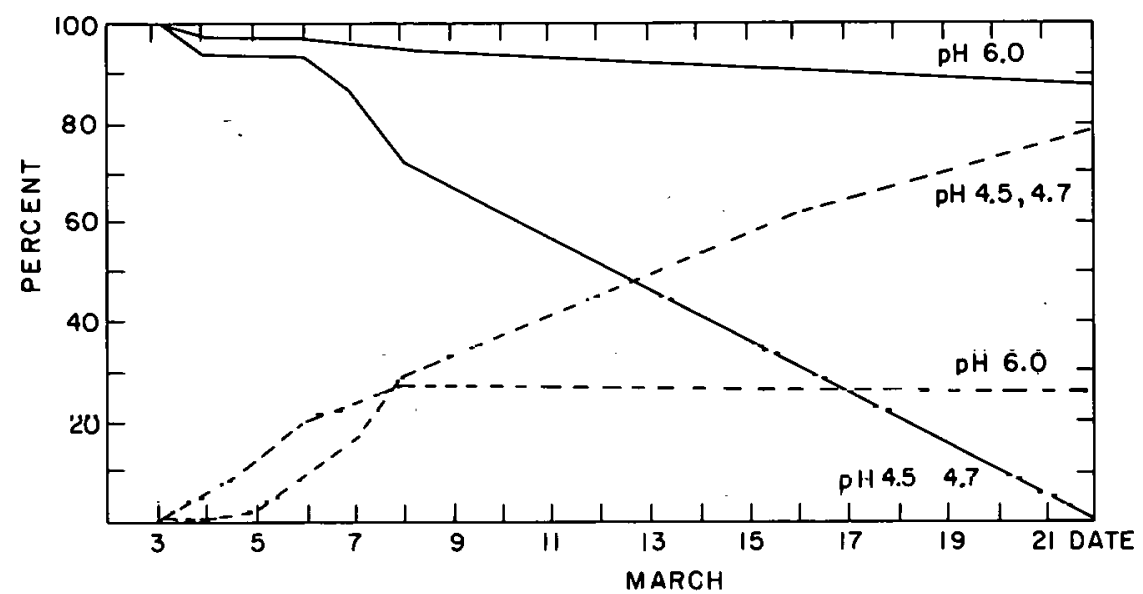

Figure 5(a). Low Conductivity Water

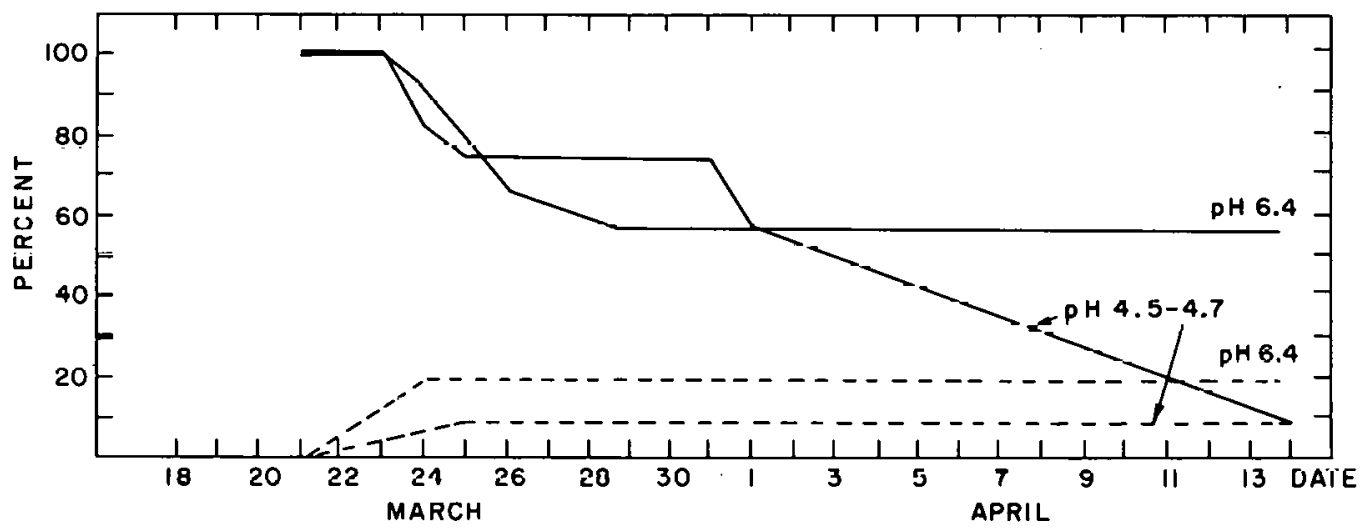

Figure 5(h). High Conductivity Water

Figure 5. Survival (-) and exuviae exchange (-) of Amphinemura sulcicollis at two $\mathrm{pH}$ levels in low conductivity water $\not 20=32$ $(a)$, and high conductivity water $\not 20=126$ (b). 
Session VI

BIOLOGICAL PROCESSES

G. Hendrey

Large amounts of filamentous algae are a common component of benthic plant communities in acidified lakes. The reasons for their excessive growth are not yet understood. Similar accumulations have been noted in streams. Experimental studies of the effects of stream acidification on algae have been conducted in Norway and in the United States. These studies may help to understand mechanisms leading to algal accumulations in lakes.

A small stream in the Hubbard Brook watershed was acidified from $\mathrm{pH} 6.1$ to $\mathrm{pH} 4.0$ by addition of $\mathrm{H}_{2} \mathrm{SO}_{4}$. Comparisons were made between the downstream treatment zone and the upstream control zone (Figures 1 to 3 ).

1. Algal biomass, as indicated by Chl. a, increased in the treatment zone. Particulate organic matter also increased markedly, and the ratio Chl. a/POM was greater in the treatment zone (Figure 4)

2. The ratio of algal production per unit biomass ( $C$ assimilated/Ch1. a as determined by the ${ }^{14} \mathrm{C}$ method) was lower in the treatment zone (Figure 5).

3. Increased biomass despite a lower specific growth rate indicates that processes of algal removal were inhibited by low $\mathrm{pH}$. These processes may include:

a. A strong inhibition of grazing by benthic invertebrates. These data were obtained and are in the process of being reduced by Ron Hall, Cornell, who is doing the invertebrate work.

b. Decomposition.

4. Data on decomposition indicated that bacterial activity was inhibited in the acidified stream (Table 1 ).

\section{ACIDIFICATION AND BIOLOGICAL PROCESSES}

1. Accumulation of organic debris (such as "felts" in Swedish lakes) due to decomposition inhibition must interfere with nutrient cycling, but the degree of interference is not known.

2. Lake clarity increases with acidity. This has been documented for clear-water lakes in the Adirondacks and in Sweden. This could be caused by precipitation of humic substances or decreased phytoplankton density.

3. Primary productivity studies:

a. In the Adirondack study, fractioning of phytoplankton biomass will be conducted in the future.

b. It is important to study effects of acidity and temperature on DIC through the water column.

\section{SUDBURY LAKES \\ (Norman Yan)}

1. Effects of acidity on phytoplankton.

a. No direct correlation is seen between algal biomass and acidity.

b. Species composition changes. For example, as acidity increases, Dinoflagellates replace Chrysophyceae. 
production.

c. DIC levels are low, creating problems with measurement for primary

2. Effects of acidity on zooplankton include a reduction in species number with increased acidity.

3. Assessment of present research efforts.

a. Biology of acidic lakes beyond the descriptive stage is virtually nonexistent.

b. Future studies must be more intensive and involve all interactions.

\section{DISCUSSION}

It was agreed that future studies must not only be more intensive, but also long term. These long-term studies are needed at several to many sites over North America, using lakes as long-term monitors of atmospheric pollution. There was not a concensus on the meaning of Chl. a as a measure of biomass. W. Dickson felt Chl. a was a poor estimate of blomass, especially when the plant is under stress. A concensus was reached on the need to uoc incubators and Fee's model for primary production studies. It was also felt that more research was needed on the effects of acidification on nutrient rerys 1 ing. The point was made that benthic algal biomass increases may inhibit the hatching ability of benthic fish eggs. 
Table 1.

Comparisons of Bacterial Number (Determined by Direct Counts

- Using Epifluorescence Microscopy), Ash-free, Dry-weight (POM), Dark Incorporation of ${ }^{14} \mathrm{C}$-acetate and Production of ${ }^{14} \mathrm{CO}_{2}$ by Benthic Communities in Norris Brook Above the Point of Acid Addition (A) and Below That Point, in the Acidified Zone (B)

\begin{tabular}{|c|c|c|c|c|c|c|c|c|}
\hline & \multicolumn{2}{|c|}{$6 / 4$} & \multicolumn{2}{|c|}{$7 / 14$} & \multicolumn{2}{|c|}{$8 / 4$} & \multicolumn{2}{|c|}{$8 / 14$} \\
\hline & $\mathrm{A}$ & B & $\mathrm{A}$ & $B$ & A & $\mathrm{B}$ & $\mathrm{A}$ & B \\
\hline$\frac{10^{6} \text { Bacteria }}{\mathrm{mg} \mathrm{POM}}$ & 1010 & 580 & 410 & 974 & 19 & 17 & 111 & 160 \\
\hline$\frac{\text { DPM }}{10^{6} \text { Bacteria }}$ & 49 & 32 & 88 & 20 & 1020 & 1123 & 715 & 663 \\
\hline $\mathrm{CO}_{2} \mathrm{DPM}$ & & & & & 927 & 503 & & \\
\hline $10^{6}$ Bacteria & & & & & & & & \\
\hline
\end{tabular}




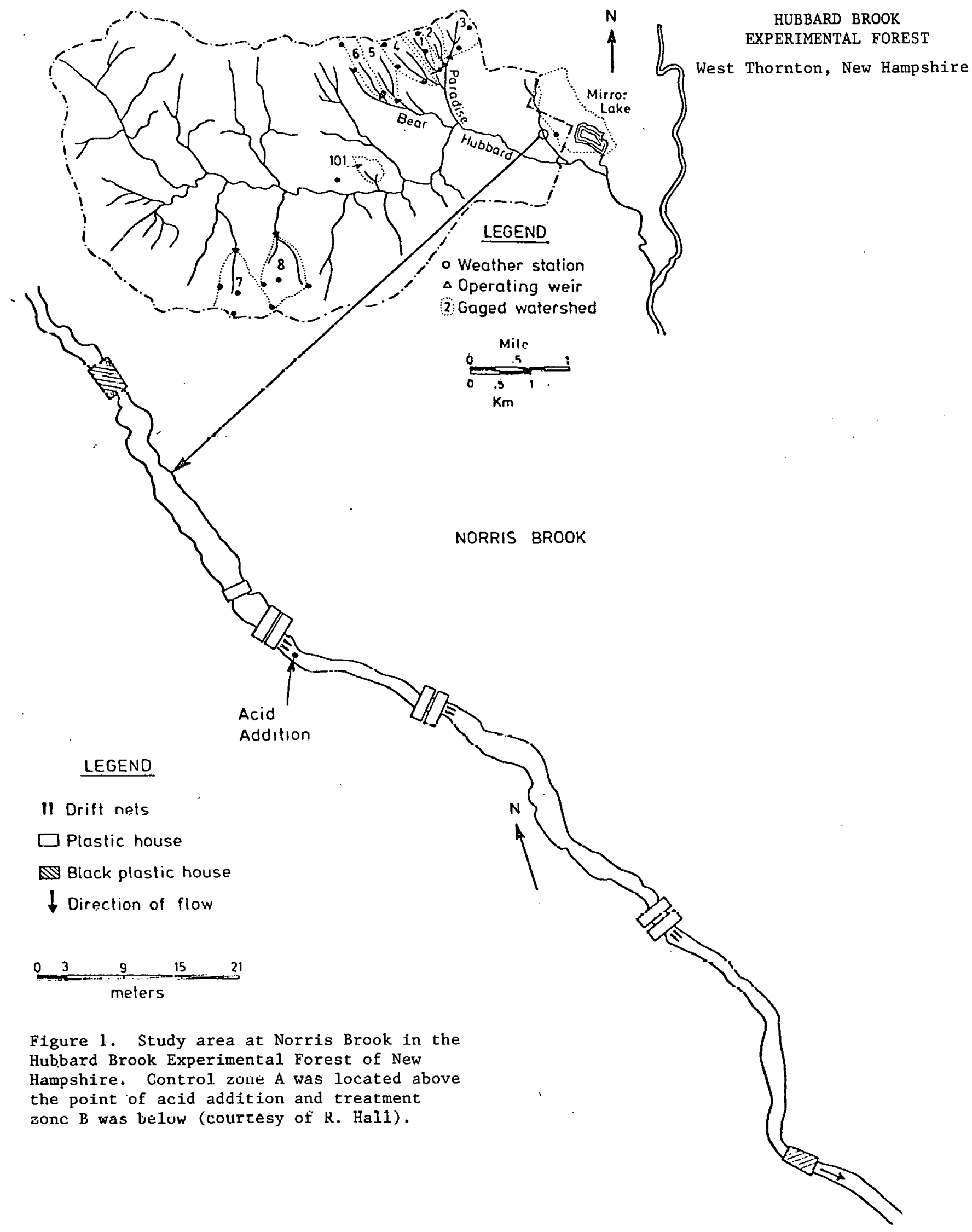





Figure 2. Changes in stream water chemistry following the addition of dilute $\mathrm{H}_{2} \mathrm{SO}_{4}$ to Norris Brook (courtesy of R. Ha11) 


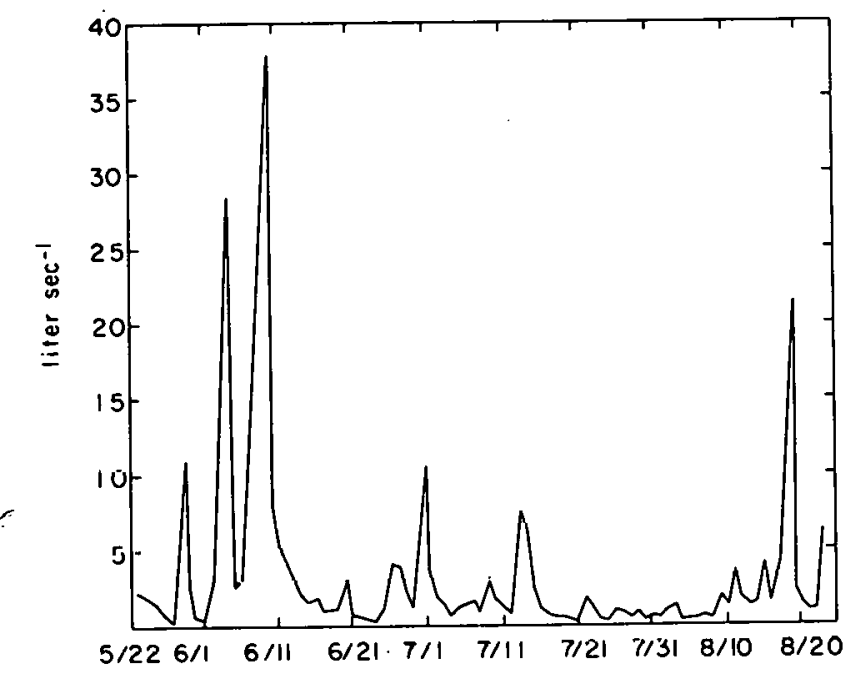

Figure 3. Daily maximum stream discharge from the study area of Norris Brook 5/22$8 / 22 / 79$.

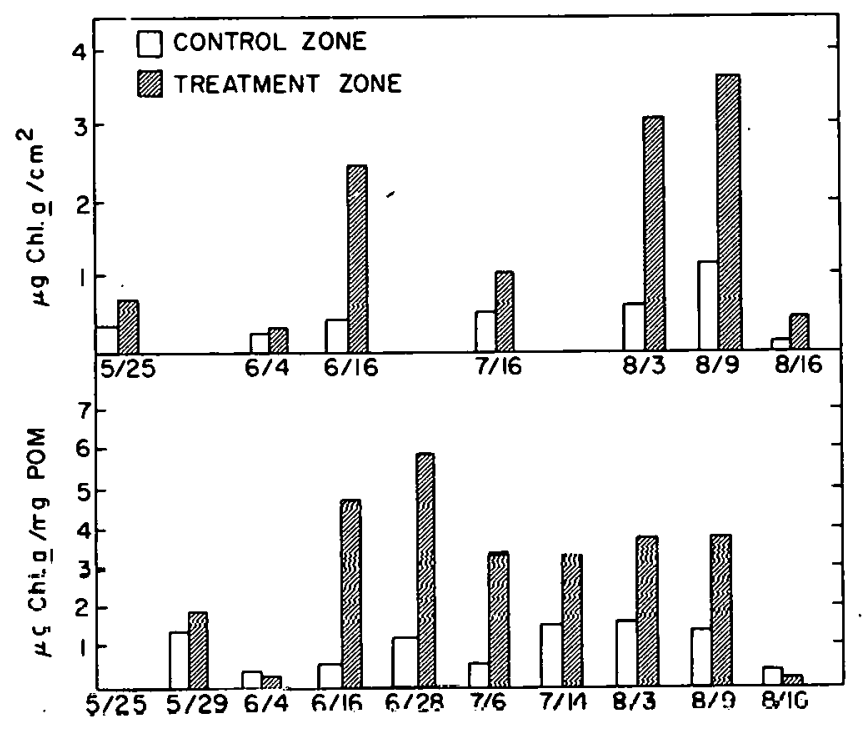

Figure 4. Argal concentrations of Chl. $\left(\mu \mathrm{gChl} . \mathrm{a} / \mathrm{cm}^{2}\right)$ and the ratio of $\mathrm{Chl}$. a to attached organic matter $(\mu \mathrm{g} \mathrm{Chl} . \mathrm{a} / \overrightarrow{\mathrm{mg}}$ PUM) in the control zone $A$ (open) and treatment zone B (hatched) of Norris Brook.

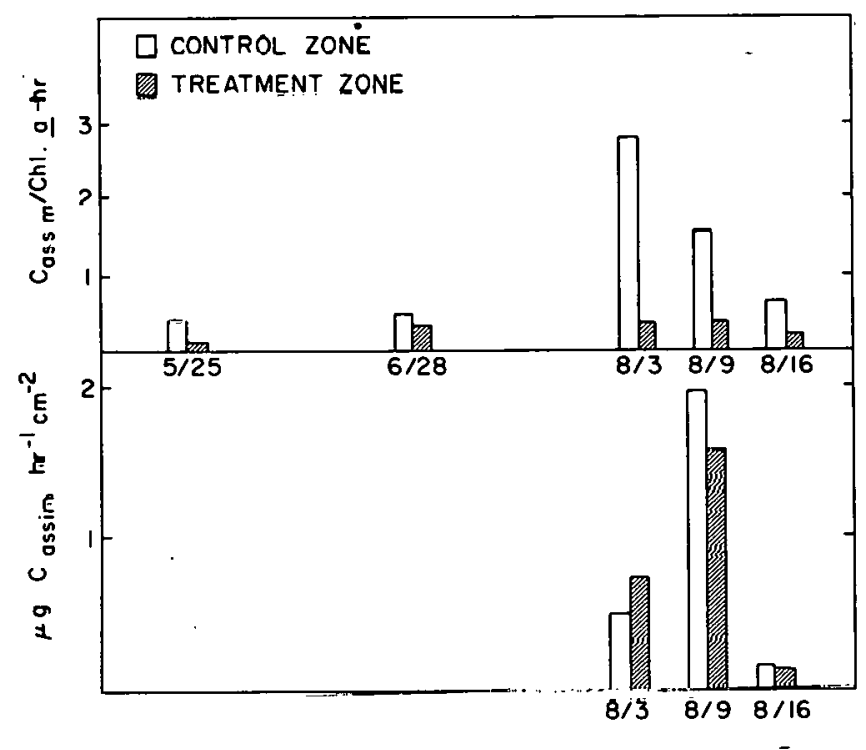

Figure 5. Specific productivity (C assim $^{\prime}$ Ch1. a hr) and areal productivity ( $\mu \mathrm{g}$ $\mathrm{C}$ assim $/ \mathrm{hr} \mathrm{cm}^{2}$ ) in the control zone $\mathrm{A}$ (open) and treatment zone $B$ (hatched) of Norris Brook. 
Session VII

TOXICITY OF METALS

C. Schofield

\section{REVIEW OF MAJOR POINTS OF AGREEMENT \\ CONCERNING ACIDIFICATION EFFECTS ON FISH POPULATIONS}

Physiological

1. The major response to acid stress is inhibition of osmoregulation. With high $\mathrm{H}^{+}$levels, $\mathrm{Na}^{+}$exchange is inhibited leading to a salt loss.

2. Other cations, particularly $\mathrm{Ca}^{++}$, mitigate this osmoregulatory imbalance by controlling cell membrane permeability. During snowmelts in southern Norway, both $\mathrm{pH}$ and $\mathrm{Ca}$ levels determine fish mortalities. In Adirondack waters, however, $\mathrm{Ca}$ levels do not appear to decrease during snowmelt to the extent that they do in Norwegian waters. Therefure, the stress due to low $\mathrm{Ca}$ at low $\mathrm{pH}$ would be less.

3. Metal toxicity. In the Adirondacks, $\mathrm{Al}$ may be more important than $\mathrm{H}^{+}$ or $\mathrm{Ca}^{++}$in fish stress and mortality. The mechanism of $\mathrm{Al}$ toxicity, however, is not known, Severe gill damage in fish has been found experimentally at AI levels of $.2 \mathrm{mg} /$ liter and greater. Whether this gill necrosis and resultant anoxia or the effect of $\mathrm{Al}$ as an acid cation disturbing the $\mathrm{Na}^{+}$pump is the cause of death is not really known.

Evidence for the importance of $\mathrm{Al}$ toxicity versus $\mathrm{H}^{+}$toxicity comes from stocking success data on Adirondack lakes. Brook trout were stocked for five years in a series of lakes and then stocking success evaluated by netting. A regression of stocking success as a function of $\mathrm{pH}$ and $\mathrm{Al}$ indicated that $\mathrm{Al}$ played the more important role. Detrimental levels of Al were .2 to $.5 \mathrm{mg} /$ liter. Laboratory, bioassays and work by W. Dickson also confirm the importance of $\mathrm{Al}$ in fish mortalities. The species of $\mathrm{Al}$ in the water are also important. Organically bound $A I$ is much less toxic than inorganic Al species.

Population Responses

1. Perturbations of fish populations in acidified watexs which have been recognized include:

a. Mass mortalities during snowmelt. Such mortalities have been well documented in Norway. No such episodic mortalities have been noted in Adirondack waters. This difference may be due to water quality differences (e.g., the small drop in Ca level during snowmelt in the Adirondacks) or just lack of observation of small scale spring fish mortalities.

b. Changes in age and size structure of the fish population. Typically, the response is a shift to older and larger fish, suggesting recruitment failure. Huwever, in Norway streams mortality for brown trout appears to occur primarily among first-year spawners (in a weakened condition following spawning). The fish population is, therefore, composed primarily of young age classes. Different life stages apparently have different susceptibilities and are exposed to different regimes of $\mathrm{pH}$ and $\mathrm{Al}$. More fleld and lab studies are necessary to elucidate the mechanisms which result in population structure shifts. 
c. Growth rates. Beamish in LaCloche Mt. lakes noted a reduction in white sucker growth in acid environments. He did not feel that the biomass of the food supply was limited. In Norway, however, brown trout have responded with increased growth in acid lakes as a result of decreased population density.

d. Decrease in recruitment. Several hypotheses: (1) decreased egg deposition elther due to spawning inhibition or gonadal deformation in adult fish (Beamish et al.); (2) increased mortality of eggs and larval fish noted, for example, in brown trout in Norway and brook trout in the Adirondacks; (3) attrition of the population as a result of periodic episodic adult mortalities leading to decreased egg deposition; and (4) decrease in the quality of the spawning habitat as a result of growths of benthic algae. All of these mechanisms may be occurring simultaneously.

2. Decreased species diversity in acidified lakes, especially below pH 5 . Below $\mathrm{pH} 4.5$, any species is rare.

3. Differences in species sensitivities. These differences in apparent sensitivities may be due to inherent differences in sensitivity or to differences in life history patterns and the $\mathrm{pH}-\mathrm{Al}$ regimes to which they are exposed at different life history stages.

4. Intrasperific differences in acid l:nlerance have al oo been fuum, parclcularly in brown trout in Norway and brook trout in the Adirondacks. The differences seem to be related to the environment from which these populations have been derived and exposed to for a long time. These suggest selection for acid tolerance. T. Hutchinson in his discussion on toxiclty of $\mathrm{pH}$ and metals to zooplankton also noted that the survival of one or a few individuals in an experiment long after the major mortality had occurred suggests the availability of genetic variation which potentially could be selected for $\mathrm{pH}$ and metal intolerance.

\section{AREAS OF DISAGREEMENT AT THE SCOTLAND WORKSHOP WHICH, THEREFORE, REQUIRE MORE RESEARCH}

Physiology

1. Synergistic and antagonistic effecto of mixed cation systems on $\mathrm{pH}$ stress. Do other cations besides $\mathrm{Ca}^{++}$increase survival at low $\mathrm{pH}^{\prime} \mathrm{s}$ ? How do $\mathrm{Ca}$ and other cations affect membrane permeability? Apparently $\mathrm{Na}$ does not decrease $\mathrm{pH}$ stress.

2. Mechanism of Al toxicity. Gill damage is evident in some cases, but not all. Al may also influence the "Na pump" vin its alllor as an "acid" cation. How do other cations (especlally $\mathrm{Ca}$ ) affect $\mathrm{Al}$ toxicity?

3. Effects of other metals (e.g., Mn and Fe). Fe does not appear to be toxic at the levels found in acid lakes. Mn effects are not known.

4. Organics appear to ameliorate Al toxicity. By tylng up other cations, they may have secondary effects on $\mathrm{pH}$ and $\mathrm{Al}$ toxicity.

5. Age and size effects on $\mathrm{pH}$ and $\mathrm{Al}$ tolerance. It has been generally thought that smaller fish would be more sensitive to $\mathrm{H}^{+}$stress because of the size - surface area relationships. Some evidence suggests that Al may be more toxic to larger fish.

6. Effect of temperature has not been studied. Must laboratory bioassays are conducted at temperatures greater than those during snowmelt, perhaps the most stressful period. 
7. Seasonal changes on the condition of the fish and the effects on its sensitivity have not been examined. Acclimation to stress may also be very important.

\section{Populations}

1. Several mechanism(s) for population decline and changes in structure have been proposed. The mechanism in a particular lake probably depends on the water chemistry regimes and life histories and sensitivities of fish species involved.

2. The role of temporal and spatial variations in water quality as determinants of population success requires more research. Are episodic mass mortalities of fish sufficient to lead to extinction of fish populations? Spatial diversity in water quality may allow survival of fish species in refuge areas or successful spawning and recruitment of fish in higher $\mathrm{pH}$ tributaries or in groundwater seepage areas in lakes otherwise at $\mathrm{pH} 4.5$ to 4.7 .

3. Are changes in growth due to changes in fish feeding behavior, changes. in food supply, changes in fish distribution relative to food availability?

4. Species differences require more attention. Most research has been on game fish, whereas cyprinids may be one of the more sensitive groups.

\section{ACCUMULATION OF METALS IN FISH IN ACID ENVIRONMENTS}

A graph of $\mathrm{Hg}$ levels in brook trout muscle as a function of fish length for Adirondack lakes indicated that fish from acid drainage lakes ( $\mathrm{pH}<5$ ) had higher $\mathrm{Hg}$ levels (for a given length) than fish from limed, seepage, or bog lakes. This suggests that humics may inhibit mobilization of $\mathrm{Hg}$ and that some $\mathrm{Hg}$ may be contributed from the watershed. It was noted that $\mathrm{Hg}$ levels in $\mathrm{fish}$ in the Adirondacks are not necessarily due to low $\mathrm{pH}$ since some lakes have high fish $\mathrm{Hg}$ content without low $\mathrm{pH}$.

$\mathrm{H}$. Hultberg noted a high correlation between $\mathrm{pH}$ and $\mathrm{Hg}$ in pike. A number of lakes had $\mathrm{Hg}$ levels in fish above the Swedish standard. Lakes remote from sources of $\mathrm{Hg}$ pollution also had high $\mathrm{Hg}$ levels in fish. He suggested that part of the increase in $\mathrm{Hg}$ in pike in acid lakes may be a result of the shift in prey the pike feed on. Methyl $\mathrm{Hg}$ in sediments also increased with decreasing $\mathrm{pH}$. A strong $\mathrm{Hg}-\mathrm{pH}$ relationship was also noted for zooplankton Hg accumulation.

P. Dillon noted that for Ontario lakes $\mathrm{Hg}$ levels in walleye appeared dependent on alkalinity. Of about 100 lakes studied, fish from lakes with alkalinities less than 300 eq./liter tended to have $\mathrm{Hg}$ levels three limes thosc in fish of similar size from higher alkalinity lakes. In Ontario, a large number of lakes have at least some fish which exceed the Ontario $\mathrm{Hg}$ limit.

Source of $\mathrm{Hg}$ Elevations in Fish

1. D. Schlinder suggested that the relation between $\mathrm{Hg}$ and $\mathrm{pH}$ may be a result of increased methylation in lakes with low $\mathrm{pH}$. A sphagnum of "felt" mass on the bottom would set up an ideal environment of methylation. A shift toward anaerobic decomposition favors methylation. Schindler noted that flooding a reservoir also resulted in elevated $\mathrm{Hg}$ in $\mathrm{fish}$ probably by favoring bacterial methylation.

2. Hg may also come in via precipitation or from the watershed. Dimethyl $\mathrm{Hg}$ is volatile. Dimethyl mercury converts to monomethyl $\mathrm{Hg}$ at low $\mathrm{pH}$. $\mathrm{Hg}$ methylation can also occur in soils. 
3. Controversy over whether $\mathrm{Hg}$ uptake is from water or food supplies. D. Schindler cited about one-half from each source on the basis isotopic $\mathrm{Hg}$ studies. Only $\mathrm{Hg}$ isotope was added to the lake and levels stabilized fairly quickly. About 50 to $60 \%$ distributed to particulates. H. Hultberg noted that most $\mathrm{Hg}$ uptake studies are probably invalid because of excess quantities of $\mathrm{Hg}$ added to the water. Studies in Holland found no uptake via gills.

4. Do other metals show uptake trends similar to $\mathrm{Hg}$ ? In the Adirondacks, only data on $\mathrm{Pb}$ are available. There appears to be some increase in $\mathrm{Pb}$ levels in fish in soft-water Adirondack lakes relative to those in the limestone belt. No real data relating $\mathrm{Pb}$ to $\mathrm{pH}$ is available. $\mathrm{P}$. Wong noted a doubling of $\mathrm{Pb}$ levels in fish with a lowering of $1 \mathrm{pH}$ unit. Methyl $\mathrm{Pb}$ increases with decreasing $\mathrm{pH}$, thereby increasing return of $\mathrm{Pb}$ from sediments.

Effects of Episodic Acid Exposures

1. The Scotland workshop concluded that episodic stresses may be crucial in population euccess. Is a pH drop in the spring in an otherwise near-neutral lake sufficient to cause population declines? It was noted that whitefish may be susceptible to decreased $\mathrm{pH}$ during onowmelt when eg8s are opawned in lakeshore waters of about $1-\mathrm{m}$ depth. Whitefish populations do seem to be disappearing in Scandinavian lakes.

2. D. Schindler noted that data on crayfish mortality rates (survival only a few days at $\mathrm{pH} 4.5$ to 5) suggest they would expire during snownelts.

3. G. Likens noted data on Norris Brook acidification project indicating increased benthic drift within 12 hours with the response essentially complete in two to three days. These reactions are on the time scale of a snowmelt episode.

4. W. Dickson noted in lakes with $\mathrm{pH}<5$, that older fish are still surviving but recruitment is low. Hatching experiments in natural waters have shown poor hatch and high sensitivity of young life stages. In other lakes, salmon one to two years old appear most sensitive. The coincidence of timing of episodes with sensitive life stages plays a very important part.

5. N. Yan noted a lake in Ontario with $\mathrm{pH} 5.7$ which showed a missiug lake trout year class due to a spring episode with $\mathrm{pH} 4.5$.

6 . F1sh spawning behaviors may shift in response to acid conditions in normal spawning habitats.

7. The potential impacts of episodic water quality change should be considered in designing and implementing experimental studies to evaluate mechanisms which contribute to fish population extinction.

Relation of Fish Diseases to Aridified Lakco

1. Any stress seems to favor developmont of fish dlsudses. Iheretore, it is quite possible that $\mathrm{pH}$ and $\mathrm{Al}$ stress could affect fieh populatious Indirectly via Incrcased disease lncidence. $\mathrm{NH}_{3}$ stress in an Italian lake has been correlated with fish gill disease. 


\section{T. HUTCHINSON PRESENTATION OF RESULTS FROM SMOKING HILLS}

Int roduction

Smoking Hills are in the western Canadian arctic. Shale cliffs collapsing; fine particles with high sulfur content and bituminous shale result in spontaneous combustion. High levels of atmospheric $\mathrm{SO}_{2}$ and sulfur aerosols existing for at least 200 but perhaps up to 10,000 years. Large number of tundra ponds in region with range of $\mathrm{pH} 1.8$ to 8.6 . Control ponds have near neutral ( $\mathrm{pH} 7.5$ to 8.5 with bicarbonates buffering) and fumigated ones very acid ( $\mathrm{pH}<4.5$ with aluminum buffering). Very few ponds in intermediate (5 to 6) $\mathrm{pH}$ range, possibly because humic acid buffering component is missing. Low $\mathrm{pH}$ has existed for a long period in these lakes. Mosses have moved into pond bottoms but not Sphagnum. Large decrease in zooplankton production with only rotifers left below pH 6.0, especially Brachionus. However, even under the most acid conditions (e.g.; $\mathrm{pH} 1.8$ and very high levels of $\mathrm{Al}, \mathrm{Fe}, \mathrm{Mn}$, and $\mathrm{Zn}$ ), some organisms still survive, e.g., Euglena murabilis. Ca levels high, about 87 to over $200 \mathrm{ppm}$. Al levels 0.5 to $\overline{693 \mathrm{pm}}$ with greater increases below pH 6.0 .

Field Experiments

Organisms suspended in vials in lakes in reciprocal transplants of invertebrates between acid and nonacid lakes and with water at the amblent $\mathrm{pH}^{\mathrm{H}}$ or $\mathrm{pH}$ altered to the reciprocal lake $\mathrm{pH}$.

1. By increasing $\mathrm{pH}$ in acid lake water, zooplankton (Daphnia, Diaptomus) survival increased. Survival improvement noted at $\mathrm{pH}>4.5$.

2. By decreasing $\mathrm{pH}$ in near-neutral lake water, survival was better at a given $\mathrm{pH}$ than in neutralized lake water. Metal concentrations caused survival differences.

3. In acid lakes, only one species of red chironomid. In nonacid lakes, more diversity of chironomids but no red species. Hemoglobin functions may be important. Red chironomids in field experiments can survive at both low and high pH's, from 2.8 to 8.2. Green chironomids from neutral ponds survive only down to about $\mathrm{pH}$ 3.5. Those that die show rapid $\mathrm{Na}$ loss. Also true for all zooplankton, i.e., rapid $\mathrm{Na}$ loss at low $\mathrm{pH}$.

4. Metal toxicity was examined by increasing $\mathrm{pH}$ in acid lake water to precipitate out metals and then re-adding metals singly, i.e., $\mathrm{Zn}, \mathrm{Al}, \mathrm{Fe}$, or Mn. Survivorship with and without metals was compared. Al was the most toxic metal. Al alone could simulate total metal water toxicity.

5. Increased $\mathrm{Ca}$ levels could increase survival slightly at low $\mathrm{pH}$ and high Al, but $\mathrm{Na}$ addition had much greater effect.

6. Presently studying $\mathrm{Na}$ loss rates with ${ }^{22} \mathrm{Na}$.

7. Pam Stokes and $T$. Hutchinson at the University of Toronto are presently studying $\mathrm{Cu}$ and $\mathrm{Ni}$ interactions and other synergistic toxic effects on algae as well as effects on metal availability $\mathrm{nr}$ organo-metal complexes. 


\section{Soil Profiles}

Soil profiles were examined at varying distances from the fumigation source. Near the Smoking Hills plumes, $\mathrm{Ca}$ levels and $\mathrm{pH}$ are low throughout the profile (down to permafrost). At intermediate distances, $\mathrm{pH}$ and $\mathrm{Ca}$ are low near the top, but both increase with increasing depth. Fairly remote from $\mathrm{SO}_{2}$ source, the $\mathrm{pH}$ is above 7 and $\mathrm{Ca}$ high throughout the soil profile. Some lakes in all these areas show $\mathrm{pH}$ 's about 3. In pond sediments, even in low $\mathrm{pH}$ soils, $\mathrm{Ca}$ levels are low. $\mathrm{Ca}$ appears to be also leached from the sediments and lost from the drainage basin. However, some elements do accumulate in the sediments, e.g., uranium and vanadium. Mn is also leached from soils. Al levels in soil are so high that increased leaching cannot effectively be picked up. 
Session VIII

LIMING

W. Dickson

Water coming from up to $2,000 \mathrm{~km}^{2}$ of land has been limed in Sweden. The term "liming" applies to any procedure whereby the $\mathrm{pH}$ of an acidified lake is raised. Soda, potash, dolomite, calcium hydroxide, calcium oxide and limestone have all been used to achieve this end; however, limestone application is the cheapest.

The lakes of southwestern Sweden typically display low alkalinity values.

It is these lakes that are subjected to the largest amounts of sulfur deposition resulting from precipitation. This is where a majority of the acid lake problem is found. In this region there are approximately 20,000 lakes with alkalinities of less than 0.1 meq./1iter.

Liming is a common practice on arable land in this area. This is primarily done to counteract the effects of acidification from fertilization and cultivation. On treated land, approximately five tons of lime per hectare are spread every three years or so. Runoff water is in the vicinity of 1 meq. alkalinity/liter. This runoff seems to provide some control of acidification in receiving waters. It has been found that if $10 \%$ of a watershed is made up of arable land receiving the usual amounts of agriculturally applied lime, runoff water that is originally acidic can combine with the agricultural runoff, thus yielding alkalinity values of $.05 \mathrm{meq} \cdot /$ liter.

The excess sulfur load that the most sensitive lakes seem to tolerate before displaying shifts in $\mathrm{pH}$ is in the vicinity of $.5 \mathrm{~g} \mathrm{~s} / \mathrm{m}^{2}$ year. The slightly less sensitive lakes show tolerances of about $1 \mathrm{~g} \mathrm{~s} / \mathrm{m}^{2}$ year before displaying similar $\mathrm{pH}$ shifts.

Lakes in southwestern Sweden have excess sulfur loads (expressed in equiva-

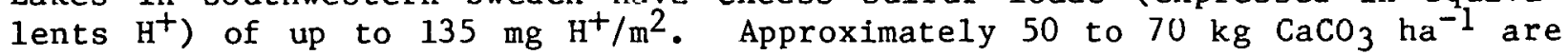
needed to neutralize this acidity.

The efficiency of liming in terms of longevity in maintaining elevated pH levels requires consideration of lake turnover times and major sources of acid input from incoming waters. In certain watersheds, where lakes with fast turnover times lie below larger lakes with slower turnover times, liming the larger lakes higher up in the watershed often result in relatively long term buffering effects for those smaller lakes displaying faster turnover times (Figure 1). There is a gradual dissolution of the limestone. Other-wise, with total immediate dissolution of the lime in a lake with a turnover time of two years, essentially all the alkalinity originating from lake water liming applications would have disappeared within that time. A lake with a turnover time of one month would have lost all its alkalinity within about one month. The dissolved $\mathrm{Ca}$ remains in the systems for somewhat longer periods of time.

As expected, both chemical and biological changes are observed in lake waters subsequent to liming. Invariably, alkalinity and $\mathrm{pH}$ will increase. Water color should increase as a result of coloring due to organic compounds at higher $\mathrm{pH}$ values. Phosphorous release from the sediments should also be observed. This is probably due to ion exchange processes with bicarbonate generated from liming. In natural situations where Al concentrations are high enough, elevations in $\mathrm{pH}$ may yield decreased phosphorous concentrations as a 
result of precipitation with Al (Figure 2). Concentrations of $\mathrm{Zn}$, $\mathrm{Mn}$, and $\mathrm{Al}$ drop with elevations in $\mathrm{pH}$ (Figures 3 , and 4 ).

Among the biological changes incurred subsequent to liming, increased phytoplankton and zooplankton diversity is commonly observed. In fish populations whose age class distributions are skewed towards the older age groups, liming results in a restoration of the younger age groups. Increases in total fish biomass have also been observed (Figure 5 ).

Caution must be taken in liming waters with high concentrations of Al. As the $\mathrm{pH}$ increases it crosses a range ( $\mathrm{Ca} 5$ to 6 ) where Al seems to be highly toxic to fish.

There have been no observations of long term detrimental effects arising from liming. Presently, it seems to be the only feasible method for providing some sort of temporary relief from acid impingement on aquatic environments. 

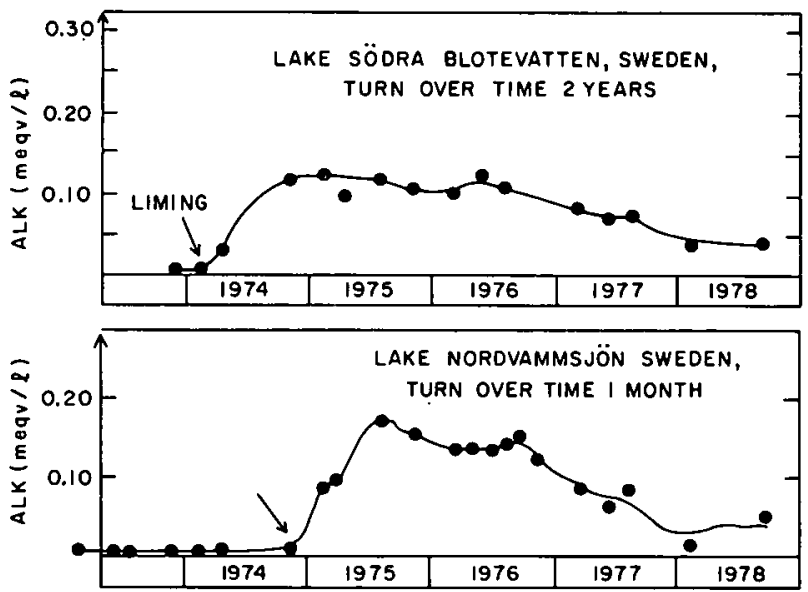

Figure 1. Effect of liming Lake Södra Blotevatten on the alkalinity of a downstream lake, Nordvammsjön, which has a much shorter water retention time.

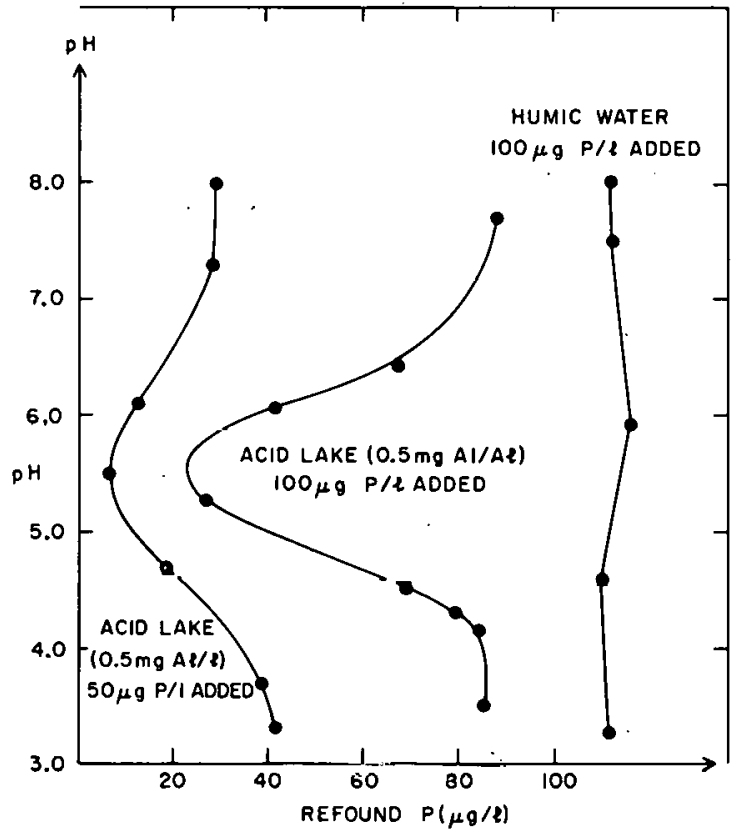

Figure 2. Phosphorus recovered (refound) after additions of 50 and $100 \mathrm{\mu g} \mathrm{P/l}$ to water from an acid lake of $\mathrm{pH} 4.1$ and $0.5 \mathrm{mg}$ $\mathrm{Al} / \ell$. Also, addition of $100 \mu \mathrm{g} \mathrm{P} / \ell$ to lumil water of $\mathrm{pH} 6.2$ containing $0.2 \mathrm{mg} / \ell$ of aluminum complexed to humus. The $\mathrm{pH}$ was adjusted to different values. The water samples were stored for 5 days before they were analyzed. 


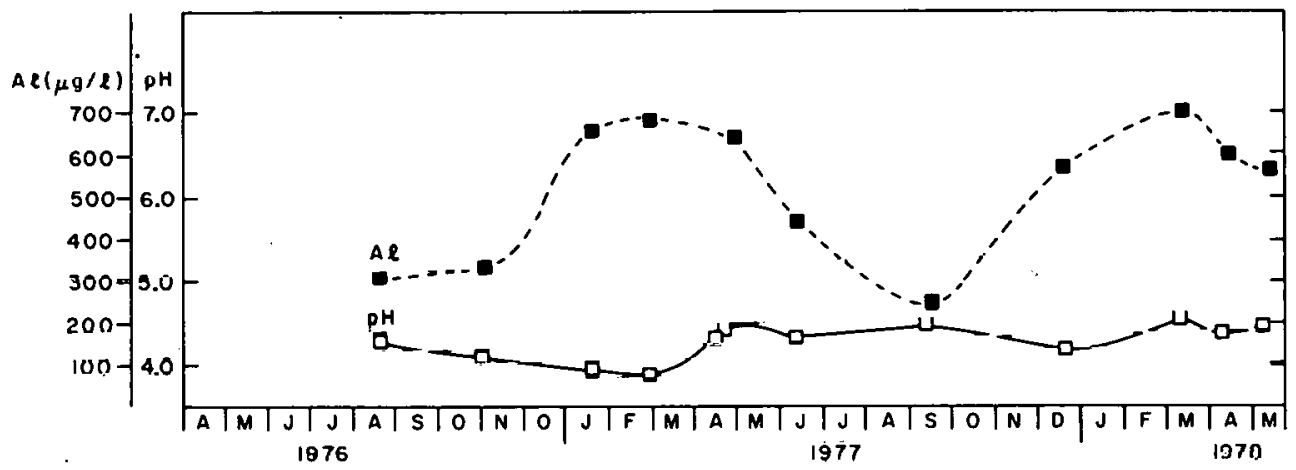

Figure 3a. Lake Horsika, Sweden

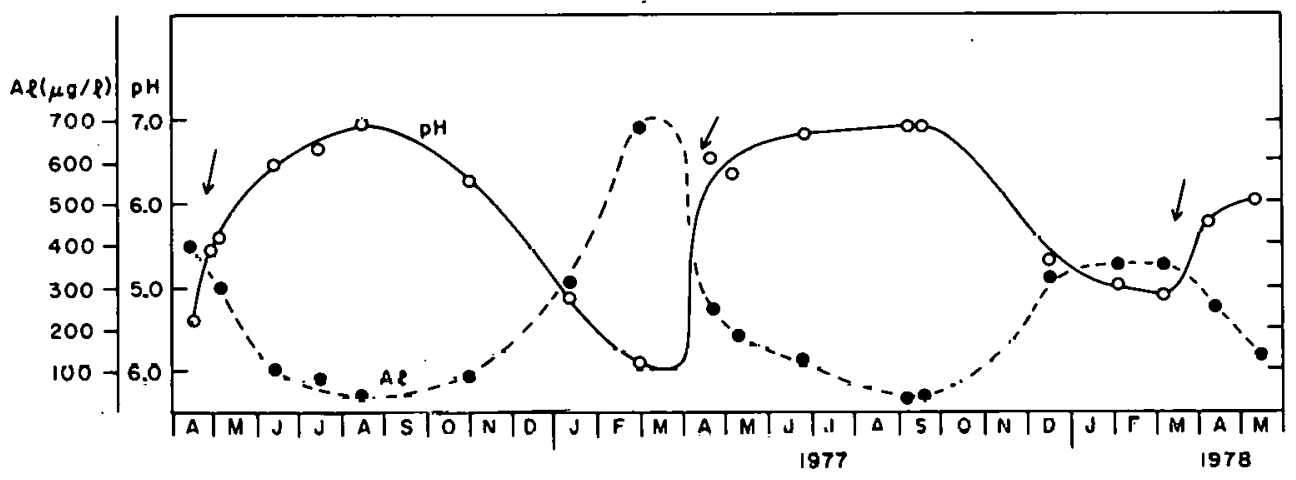

Figure 3(b). Lake Rävekärr, Sweden

Figure 3. Changes in aluminum ronrentratione with pH in lakes Horsika (a) and Rävckärr (b). 


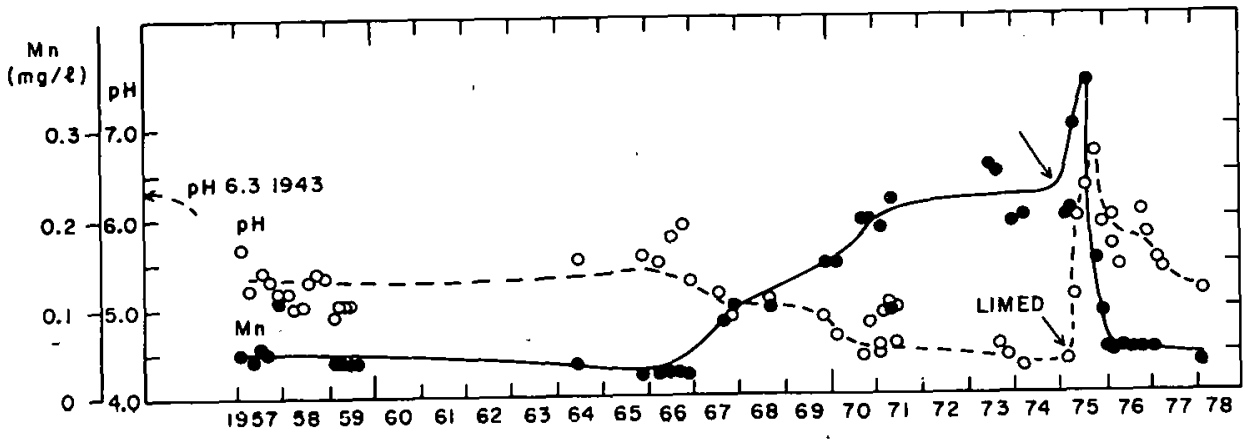

Figure 4. Variations in Mn concentrations with $\mathrm{pH}$ in Lake Stora Skarsjön between 1957 and 1978 .

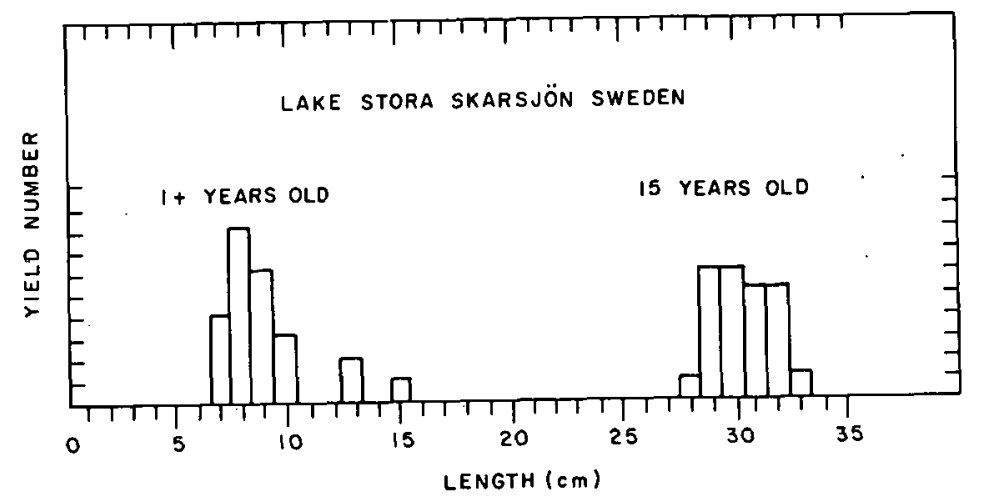

Figure 5. Age class distributions of fish in Stora Skarsjön after liming which took place in April.1975. The pH history for this lake is shown in Figure 4 . 
Session IX

SUMMING-UP AND RECOMMENDATIONS

G. E. Likens

\section{SUMMING-UP}

A number of points have been stressed during this workshop:

1. Study of acid precipitation is multidisciplinary, involving geology, meteorology, chemistry, limnology. Thus it is essential to standardize the terminology, e.g., what we mean by the word "alkalinity." Procedures must also be standardized so that we know what we can measure. Then we must ask. what we should measure. This is easier to answer for physical studies than for biological studies. Natural ernsystems are quite vallable, finr example, the rhemistry of precipilation falling through a coniferous forcst differs markedly fruill that of a deciduous forest. Similarly, the geology, chemistry and hydrology differ greatly among ecosystems. Thus il 1.s difficult to make goncralizatiuns. It 1 a also easy to misunderstand one another if we are not precise about terminology.

2. Several major questions can be identified:

a. What is the magnitude of the acid precipication problem In North America? Synuptic studies in Scandanavia have given good overview of what is happening there. This is not true in North America. An overview of the current status is needed.

b. What is the source of the problem? The consensus at this meeting is that the source is $\mathrm{SO}_{x}$ and $\mathrm{NO}_{x}$ emissions from burning of fossil fuel.

3. What are the costs of the problen? The cerrestrial system provides a "free" buffer effect which reduces impacts on ecosystems. This buffer capacity can be used up. This "free" service actually has a value which should be included in any economic calculations relating to did prccipitatiul. We do not get a full cost-benefit analysis of the problem.

4. What can we predict? How fast will a lake become acid? We need some sort of sensitivity analysis which includes:

a. watershed area/lake area;

b. elevation (orographic cffects, dralnage patterns);

c. $\mathrm{SO}_{4}$ reduction system (proposed by Srhindler);

d. denitrification system (proposed by Dickson);

e. geological substrate;

f. buffering of acid input by canopy, litter, soil,

stream channels.

5. How can we evaluate whether acidification of a lake has taken place? The model of Henriksen may provide a useful tool. It is necessary to establish the theoretical, biological, and chemical bases of this model. (It may be equivalent to the Vollenweider-Dillon model of lake eutrophication.)

6. What will be the effect if acid precipitation is eliminated? Biological effects are poorly known, more so in North America than in Scandinavla. Biological response is highly variable and biological systems are quite resilient. This complexity is an aspect of biological studies that is both fascinating and frustrating. 


\section{RECOMMENDATIONS: A PRIORITY-RATED LIST}

Long-term studies of very carefully selected lakes are needed. Undertake comparative studies of these systems, including quantitative analyses of the vegetation, soils, geology, and hydrology of the watersheds.

Experimental manipulations of whole systems. In addition to studies of clear-water, oligotrophic lakes such as those in the ELA, the following,types of lakes should be studied by experimental manipulations:

$$
\begin{aligned}
& \text { a. brown water types, } \\
& \text { b. dimictic lakes, } \\
& \text { c. lakes of varying flushing rates. }
\end{aligned}
$$

Carefully planned lab and field studies:

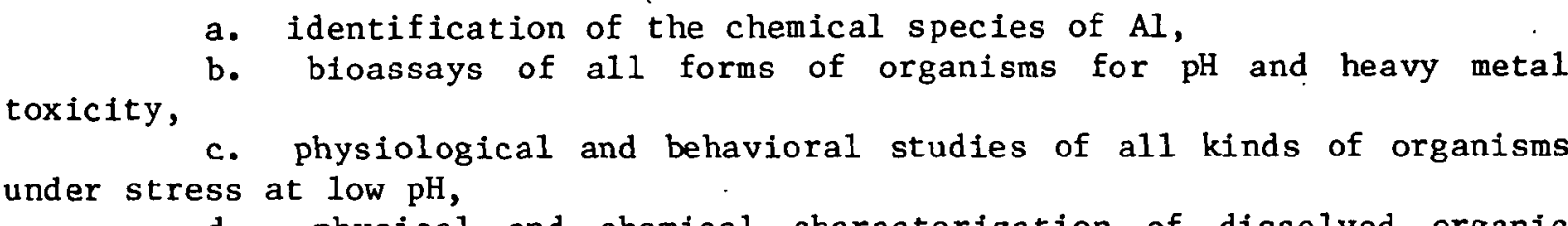

matter,

d. physical and chemical characterization of dissolved organic

e. chemical transformations during draining through soils,

f. intertrophic level effects such as grazing and competition.

The studies of palliative measures, such as lake liming, are not: appropriate to this effort.

Predictive answers to questions of acidification will be much more difficult than the above studies because they must include atmospheric chemistry, terrestrial, and stream ecosystem effects before impinging on a lake.

\section{DISCUSSION}

Schindler reintroduced the problem of base line $\mathrm{pH} . \mathrm{SO}_{2}$ deposition data indicate that studies should be undertaken in the Southern Hemisphere. Studies of $\mathrm{SO}_{4}$ deposition in the Greenland icecap would also be useful for obtaining a record of fossil fuel use.

Davis indicated the importance of paleolimnology studies to reconstruct previous lake acidity conditions.

Kramer noted the lack of knowledge about natural $\mathrm{SO}_{2}$ sources. This definitely needs resolution.

Schindler mentioned that North America is apparently being affected at a more rapid rate than Scandianavia has been. This necessitates quick action. Various energy sources were discussed, socio-economic analysis indicated as important for evaluation.

There was a consensus that an attempt must be made to stimulate public interest. Emphasis should be placed on synoptic surveys of North American lakes in order to identify sensitive areas.

Likens reemphasized long-term studies with we11-known parameters so that mass balance budgets can be constructed. 